\title{
The transcriptional repressor orphan nuclear receptor TLX is responsive to
}

xanthines

Giuseppe Faudone ${ }^{\mathrm{a}}$, Whitney Kilua, Xiaomin $\mathrm{Ni}^{\mathrm{a}, \mathrm{b}}$, Apirat Chaikuad ${ }^{\mathrm{a}, \mathrm{b}}$, Sridhar Sreeramulu ${ }^{\mathrm{c}}$, Pascal Heitel $^{\mathrm{a}}$, Harald Schwalbe ${ }^{\mathrm{c}}$, Stefan Knapp ${ }^{\mathrm{a}, \mathrm{b}}$, Manfred Schubert-Zsilavecz ${ }^{\mathrm{a}}$, Jan Heering ${ }^{\mathrm{d}}$, and Daniel Merk ${ }^{\mathrm{a}, \mathrm{e} *}$

a Institute of Pharmaceutical Chemistry, Goethe University Frankfurt, D-60438 Frankfurt, Germany

b Structural Genomics Consortium, BMLS, Goethe University Frankfurt, D-60438 Frankfurt, Germany

${ }^{c}$ Center for Biomolecular Magnetic Resonance (BMRZ), Institute for Organic Chemistry and Chemical Biology, Goethe University Frankfurt, D-60438 Frankfurt, Germany

${ }^{d}$ Fraunhofer Institute for Translational Medicine and Pharmacology ITMP, D-60596 Frankfurt, Germany

e Department of Pharmacy, Ludwig-Maximilians-Universität München, D-81377 Munich, Germany

*Correspondence to: merk@pharmchem.uni-frankfurt.de

\section{- SUPPORTING INFORMATION FOR PUBLICATION -}

\section{Table of Contents}

Supplementary Figures, Tables \& Schemes …..................................................... 2

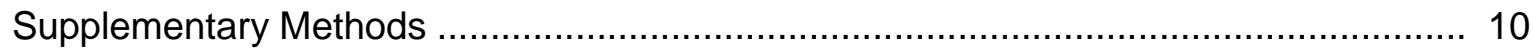

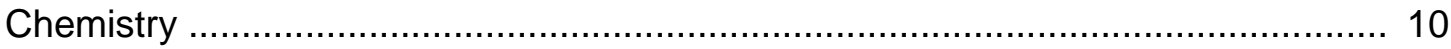

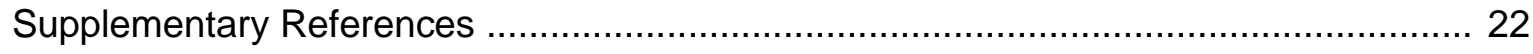




\section{Supplementary Figures, Tables \& Schemes}

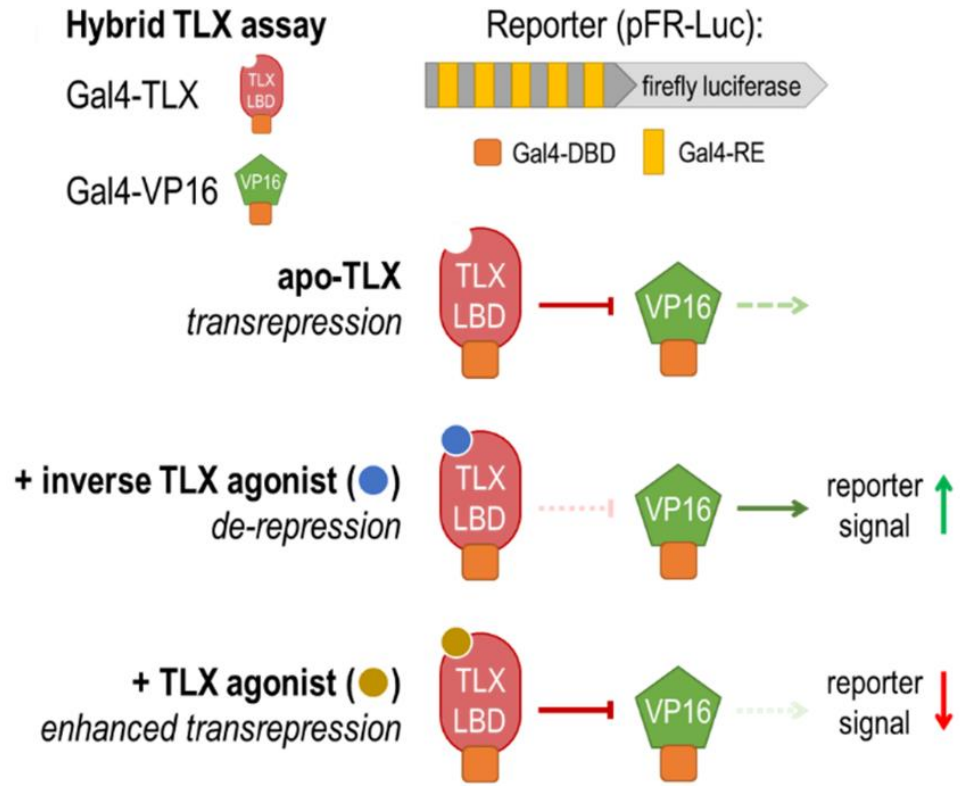

Figure S1. Schematic representation of the VP16/TLX assay ${ }^{1}$.

reporter (ff)

control (ren)
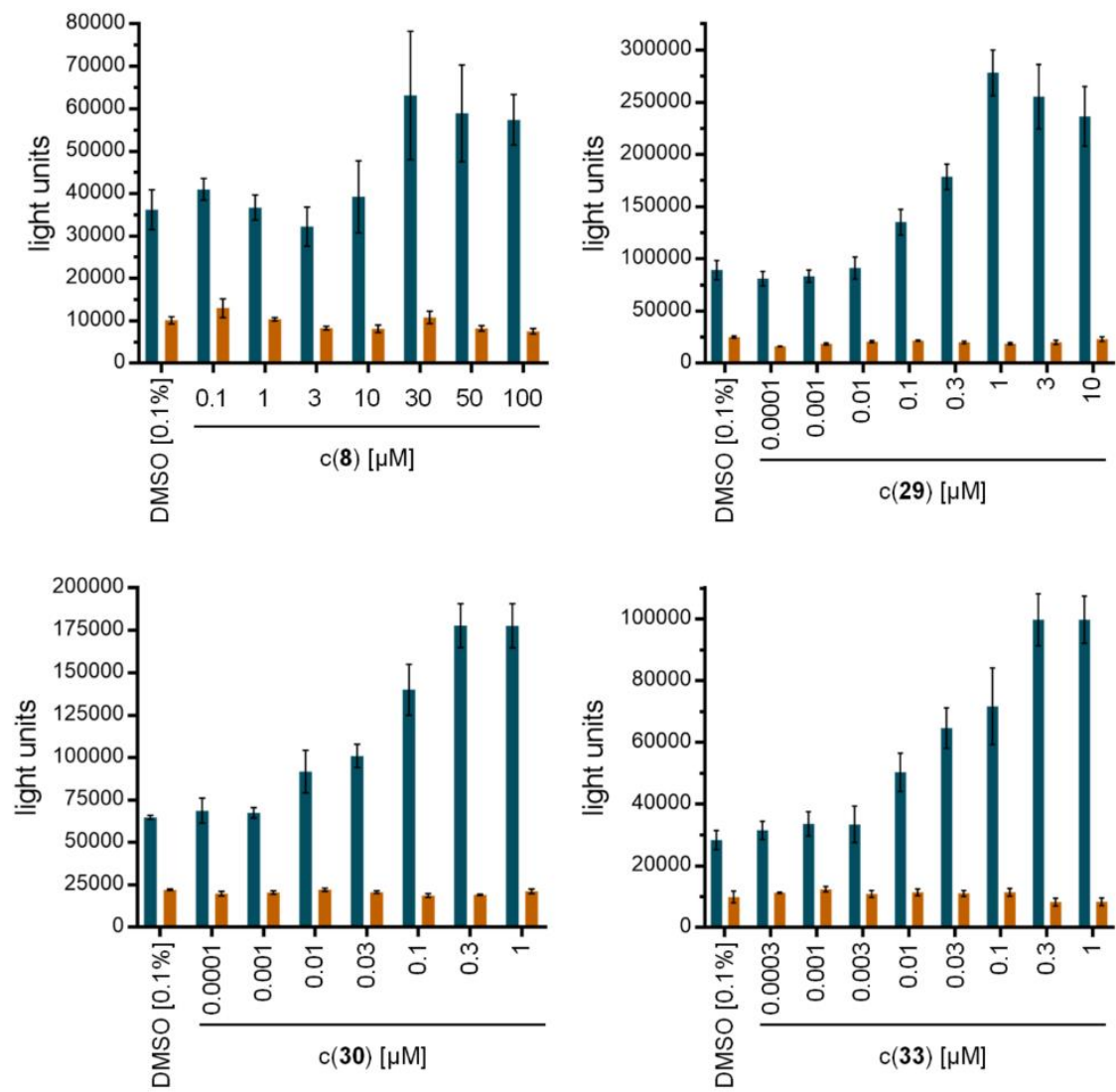

Figure S2. Reporter (firefly luciferase) and control (renilla luciferase) data for the key compounds 8, 29, 30 and $\mathbf{3 3}$ from the VP16/TLX reporter gene assay. Data are the mean \pm S.E.M.; $n \geq 3$. 


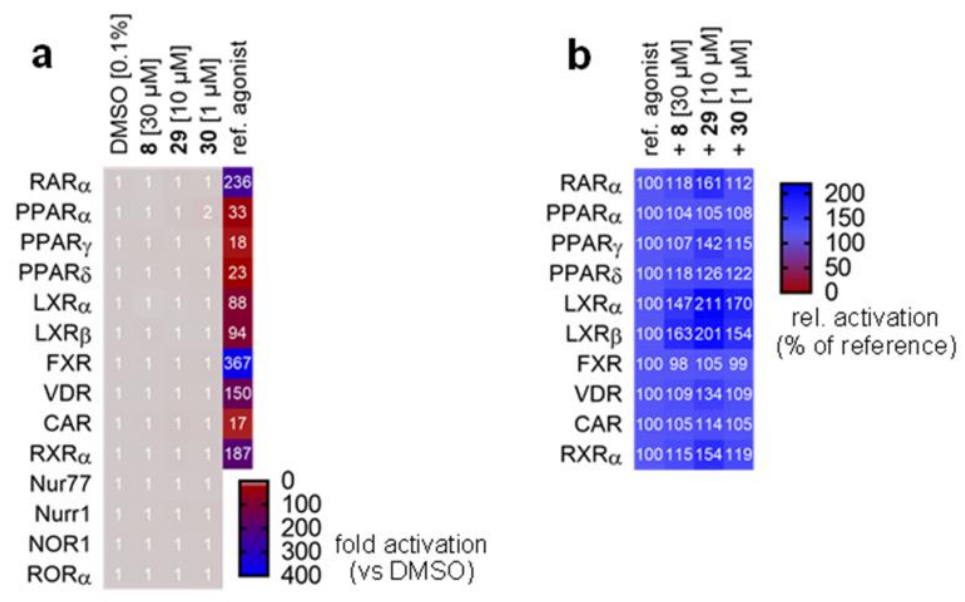

Figure S3. Selectivity profiles of $\mathbf{8}, \mathbf{2 9}$ and $\mathbf{3 0}$ amongst nuclear receptors alone (a) and in competition with reference agonists (b). Except additive effects with the LXR reference agonist, no nuclear receptor activation or antagonism were observed. All assays were conducted in a uniform Gal4 format in

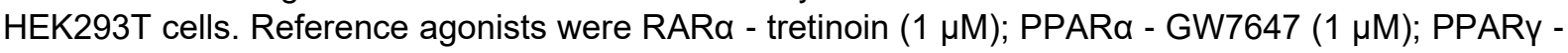

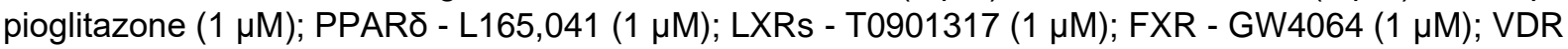
- calcitriol $(1 \mu \mathrm{M})$; CAR - CITCO $(1 \mu \mathrm{M})$; RXR $\alpha$ - bexarotene $(1 \mu \mathrm{M})$. Heatmaps show mean fold activation compared to DMSO $(0.1 \%)$ control (a) and mean relative activation compared to the activity of the respective reference agonist (b). $n=3$.

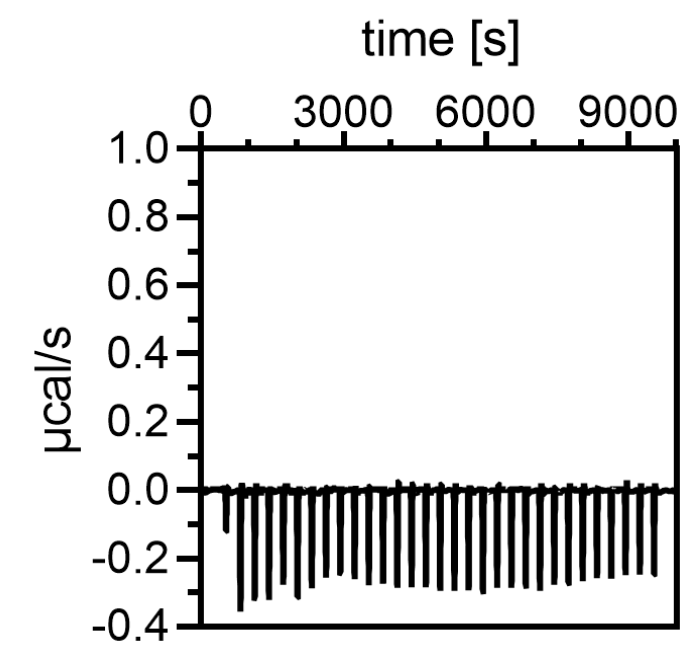

Figure S4. Representative control isothermal titration calorimetry (ITC) experiment. Buffer was titrated to the TLX LBD $(40 \mu \mathrm{M})$. 

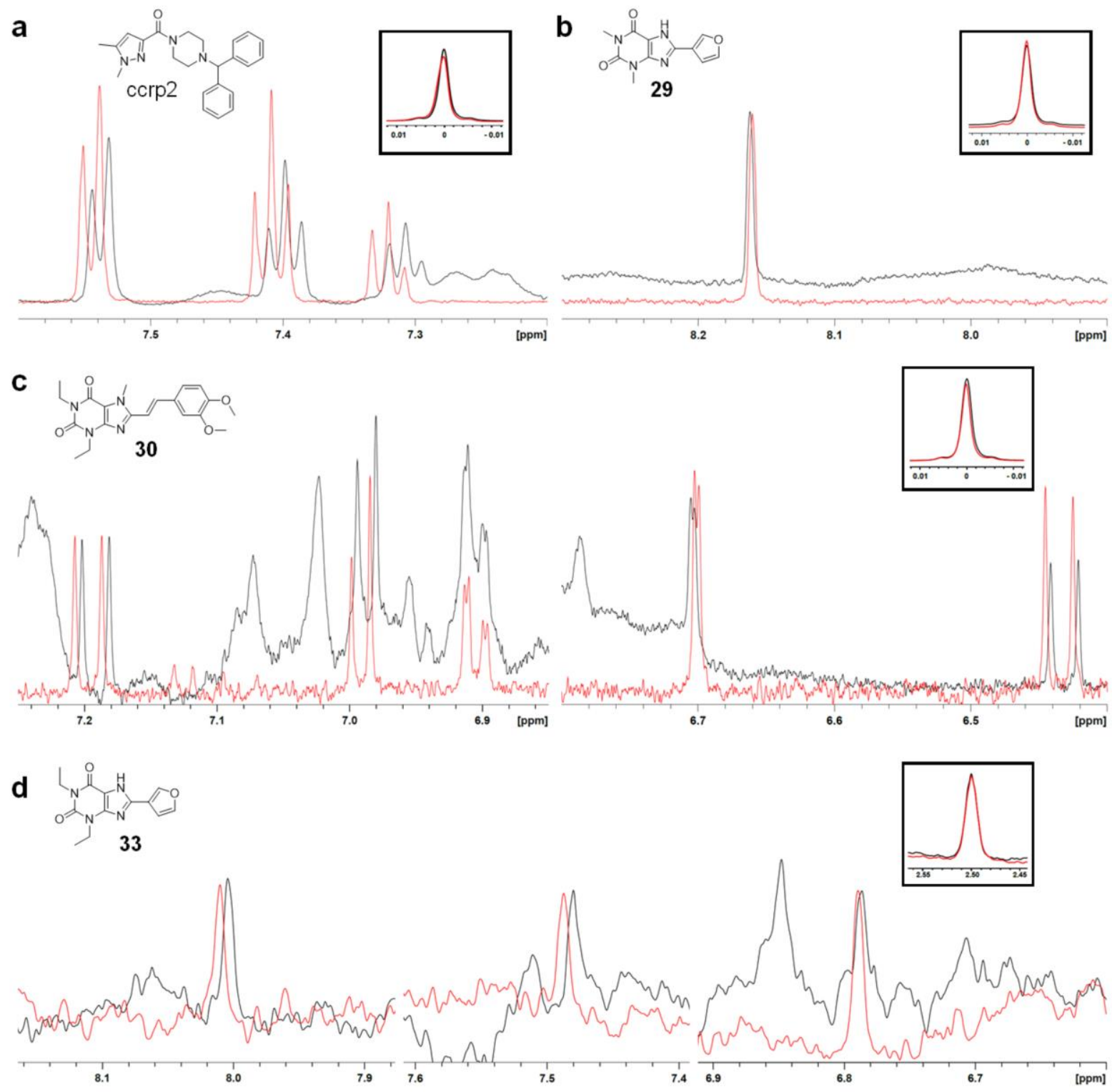

Figure S5. NMR spectra of TLX ligands in absence (red) and presence (black) of recombinant TLX LBD. Reference TLX ligand ccrp2² (a), 29 (b), 30 (c) and $\mathbf{3 3}$ (d) bind to the TLX LBD as observed by chemical shift perturbations. Spectra are normalized (box) to TMSP-Na (a-c) or DMSO- $d_{6}(d)$. 


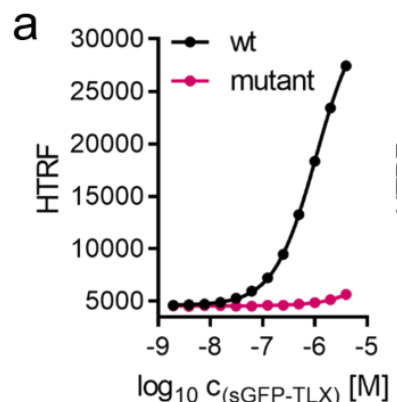

$\log _{10} \mathrm{C}_{\text {(sGFP-TLX) }}$ [M]
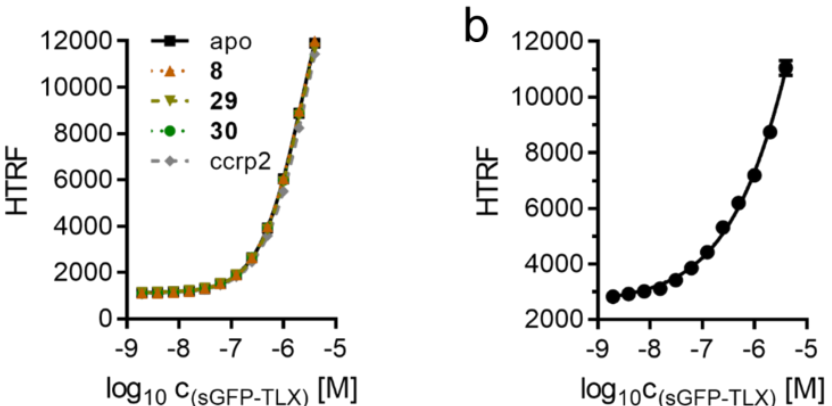

Figure S6. (a) TLX specifically interacts with the Atro box sequence ${ }^{3}$, an interaction incompetent mutant ${ }^{4}$ was not bound. Data are the mean $\pm S D ; N=3$. TLX-atrobox affinity was not modulated by $\mathbf{8 , 2 9 , 3 0}$ or the reference ligand ccrp2. All compounds were used at $10 \mu \mathrm{M}$. Data are the mean $\pm S D ; N=3$. (b) Titration of $\mathrm{Tb}^{3+}$-cryptate-labeled NCoR1 with sGFP-labeled TLX also confirmed a TLX-NCoR1 interaction but addition of TLX ligands had no effect. All compounds were used at $10 \mu \mathrm{M}$. Data are the mean $\pm S D ; N=3$.

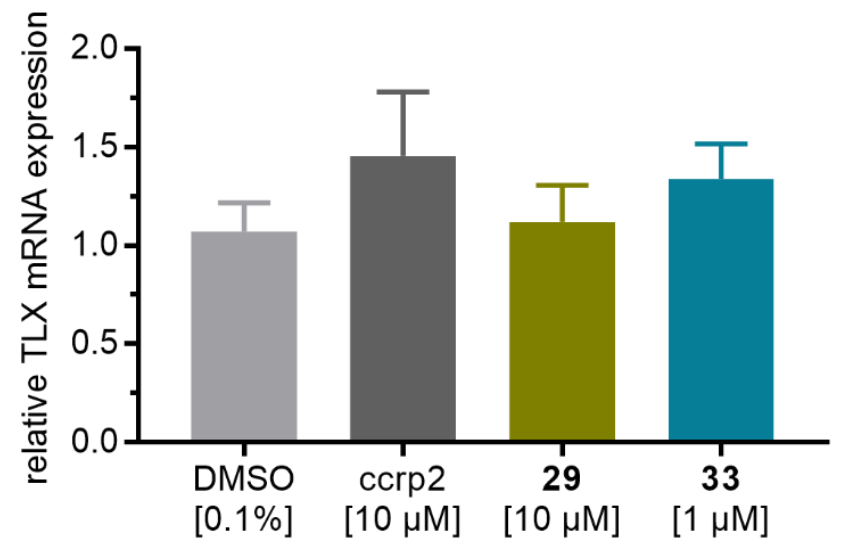

Figure S7. The reference TLX ligand ccrp2 $(10 \mu \mathrm{M})$, and the xanthines $29(10 \mu \mathrm{M})$ and $33(1 \mu \mathrm{M})$ did not alter TLX expression in glioblastoma cells. Data are mean \pm S.E.M. relative mRNA expression; GAPDH as reference gene; $n=8$. 
Table S1. In vitro potencies of xanthine derivatives as adenosine receptor antagonists according to literature. Activity on TLX for comparison. Values refer to different species as indicated: (c) - cow, (d) dog, (gp) - guinea pig, (h) - human, (m) - mouse, (r) - rat, (rb) - rabbit, (s) - sheep; n.d. - no data; for some xanthines, no distinguished values for $A_{2 A}$ and $A_{2 B}$ but only data for $A_{2}$ are available.

\begin{tabular}{|c|c|c|c|c|}
\hline ID & $A_{1}$ & $A_{2}$ & $\mathrm{~A}_{3}$ & $I_{50}(T L X)$ \\
\hline 1 & $\begin{array}{l}\mathrm{K}_{\mathrm{i}}=6.6 \pm 0.3 \mu \mathrm{M}^{5,[\mathrm{a}]} \\
\mathrm{K}_{\mathrm{i}}=17 \mu \mathrm{M}^{6,[\mathrm{~b}]} \\
\mathrm{K}_{\mathrm{i}}=11,400 \mathrm{nM}^{7,[\mathrm{c}]} \\
\mathrm{K}_{\mathrm{i}}=36,000 \mathrm{nM}(\mathrm{r})^{8,[\mathrm{~d}]}\end{array}$ & $\begin{array}{l}\mathrm{K}_{\mathrm{i}}=1.9 \mu \mathrm{M}^{6,[\mathrm{~b}]} \\
\mathrm{A}_{2 \mathrm{~A}} \\
\mathrm{~K}_{\mathrm{i}}=36,200 \mathrm{nM}^{7,[\mathrm{c}]} \\
\mathrm{K}_{\mathrm{i}}=47,000 \mathrm{nM}(\mathrm{r})^{8,[\mathrm{~d}]} \\
\mathrm{A}_{2 \mathrm{~B}} \\
\mathrm{~K}_{\mathrm{i}}=6,600 \mathrm{nM}(\mathrm{h})^{8,[\mathrm{~d}]}\end{array}$ & $\begin{array}{l}11.1 \pm 1.6 \% \%^{7,[c]} \\
K_{i}>100,000 n M(r)^{8,[d]}\end{array}$ & $9 \pm 3 \mu \mathrm{M}$ \\
\hline 2 & $\mathrm{~K}_{\mathrm{i}}=130 \pm 20 \mu \mathrm{M}^{5,[\mathrm{a}]}$ & n.d. & n.d. & inactive at $100 \mu \mathrm{M}$ \\
\hline 3 & $\begin{array}{l}\mathrm{K}_{\mathrm{i}}=87 \mu \mathrm{M}^{5,[\mathrm{a}]} \\
\mathrm{K}_{\mathrm{i}}=35 \mu \mathrm{M}^{6,[\mathrm{~b}]} \\
\mathrm{K}_{\mathrm{i}}=35,000 \mathrm{nM}^{7,[\mathrm{c}]} \\
\mathrm{K}_{\mathrm{i}}=100,000 \mathrm{nM}(\mathrm{r})^{8,[\mathrm{~d}]}\end{array}$ & $\begin{array}{l}\mathrm{K}_{\mathrm{i}}=240 \mu \mathrm{M}^{6,[\mathrm{~b}]} \\
\mathrm{A}_{2 \mathrm{~A}} \\
38.0 \pm 0.9 \% 7,[\mathrm{c}] \\
\mathrm{K}_{\mathrm{i}}=59,000 \mathrm{nM}(\mathrm{r})^{8,[\mathrm{~d}]} \\
\mathrm{A}_{2 \mathrm{~B}} \\
\mathrm{~K}_{\mathrm{i}}=87,000 \mathrm{nM}(\mathrm{r})^{8,[\mathrm{~d}]} \\
\end{array}$ & $\begin{array}{l}18.1 \pm 6.7 \% \%^{7,[c]} \\
K_{i}>100,000 n M(r)^{8,[d]}\end{array}$ & inactive at $100 \mu \mathrm{M}$ \\
\hline 4 & $\begin{array}{l}\mathrm{K}_{\mathrm{i}}=97 \pm 10 \mu \mathrm{M}^{5,[\mathrm{a}]} \\
52.3 \pm 7.9 \% 7,[\mathrm{c}] \\
\mathrm{K}_{\mathrm{i}}=33,000 \mathrm{nM}(\mathrm{r})^{8,[\mathrm{~d}]}\end{array}$ & $\begin{array}{l}\mathrm{A}_{2 \mathrm{~A}} \\
37.7 \pm 4.9 \% \%^{7,[\mathrm{c}]} \\
\mathrm{K}_{\mathrm{i}}=59,000 \mathrm{nM}(\mathrm{r})^{8,[\mathrm{~d}]} \\
\mathrm{A}_{2 \mathrm{~B}} \\
\mathrm{~K}_{\mathrm{i}}=97,000 \mathrm{nM}(\mathrm{h})^{8,[\mathrm{~d}]}\end{array}$ & $\begin{array}{l}16.4 \pm 9.6 \% \%^{7,[c]} \\
K_{i}>100,000 \mathrm{nM}(r)^{8,[d]}\end{array}$ & inactive at $100 \mu \mathrm{M}$ \\
\hline 5 & $\begin{array}{l}\mathrm{K}_{\mathrm{i}}=4.8 \pm 0.8 \mu \mathrm{M}^{5,[\mathrm{e}]} \\
\mathrm{K}_{\mathrm{i}}=6,770 \mathrm{nM}(\mathrm{h})^{9,[\mathrm{e}]} \\
\mathrm{K}_{\mathrm{i}}=14,000 \mathrm{nM}(\mathrm{r})^{9,[\mathrm{e}]} \\
\mathrm{K}_{\mathrm{i}}=8,740 \mathrm{nM}(\mathrm{r})^{9,[\mathrm{e}]} \\
\mathrm{K}_{\mathrm{i}}=7,060 \mathrm{nM}(\mathrm{gp})^{9,[\mathrm{e}]} \\
\mathrm{K}_{\mathrm{i}}=4,710 \mathrm{nM}(\mathrm{rb})^{9,[\mathrm{e}]} \\
\mathrm{K}_{\mathrm{i}}=9,050 \mathrm{nM}(\mathrm{s})^{9,[\mathrm{e}]} \\
\mathrm{K}_{\mathrm{i}}=6,330 \mathrm{nM}(\mathrm{c})^{9,[\mathrm{e}]}\end{array}$ & $\begin{array}{l}\mathrm{A}_{2 \mathrm{~A}} \\
\mathrm{~K}_{\mathrm{i}}=1,710 \mathrm{nM}(\mathrm{h})^{9,[\mathrm{e}]} \\
\mathrm{K}_{\mathrm{i}}=6,700 \mathrm{nM}(\mathrm{h})^{9,[\mathrm{e}]} \\
\mathrm{K}_{\mathrm{i}}=22,000 \mathrm{nM}(\mathrm{r})^{9,[\mathrm{e}]} \\
\mathrm{K}_{\mathrm{i}}=25,300 \mathrm{nM}(\mathrm{r})^{9,[\mathrm{e}]} \\
\mathrm{A}_{2 \mathrm{~B}} \\
\mathrm{~K}_{\mathrm{i}}=9,070 \mathrm{nM}(\mathrm{h})^{9,[\mathrm{e}]} \\
\mathrm{K}_{\mathrm{i}}=74,000 \mathrm{nM}(\mathrm{h})^{9,[\mathrm{e}]} \\
\mathrm{K}_{\mathrm{i}}=15,100 \mathrm{nM}(\mathrm{r})^{9,[\mathrm{e}]} \\
\mathrm{K}_{\mathrm{i}}=5,630 \mathrm{nM}(\mathrm{m})^{9,[\mathrm{e}]} \\
\mathrm{K}_{\mathrm{i}}=11,000 \mathrm{nM}(\mathrm{gp})^{9,[\mathrm{e}]} \\
\mathrm{K}_{\mathrm{i}}=17,700 \mathrm{nM}(\mathrm{rb})^{9,[\mathrm{e}]}\end{array}$ & $\begin{array}{l}\mathrm{K}_{\mathrm{i}}=22,300 \mathrm{nM}(\mathrm{h})^{9,[\mathrm{e}]} \\
\mathrm{K}_{\mathrm{i}}=86,400 \mathrm{nM}(\mathrm{h})^{9,[\mathrm{e}]} \\
\mathrm{K}_{\mathrm{i}}>100,000 \mathrm{nM}(\mathrm{r})^{9,[\mathrm{e}]} \\
\mathrm{K}_{\mathrm{i}}=85,000 \mathrm{nM}(\mathrm{r})^{9,[\mathrm{e}]} \\
\mathrm{K}_{\mathrm{i}}>100,000 \mathrm{nM}(\mathrm{d})^{9,[\mathrm{e}]}\end{array}$ & $10 \pm 2 \mu \mathrm{M}$ \\
\hline 6 & $\begin{array}{l}\mathrm{K}_{\mathrm{i}}=4.5 \mu \mathrm{M}^{5,[\mathrm{a}]} \\
\mathrm{K}_{\mathrm{i}}=30,000 \mathrm{nM}^{7,[\mathrm{c}]} \\
\mathrm{K}_{\mathrm{i}}=21,000 \mathrm{nM}(\mathrm{r})^{8,[\mathrm{~d}]}\end{array}$ & $\begin{array}{l}\mathrm{A}_{2 \mathrm{~A}} \\
\mathrm{~K}_{\mathrm{i}}=19,400 \pm 3,500 \mathrm{nM}^{7,[\mathrm{c}]} \\
\mathrm{K}_{\mathrm{i}}=32,000 \mathrm{nM}(\mathrm{r})^{8,[\mathrm{~d}]} \\
\mathrm{A}_{2 \mathrm{~B}} \\
\mathrm{~K}_{\mathrm{i}}=4,500 \mathrm{nM}(\mathrm{h})^{8,[\mathrm{~d}]}\end{array}$ & $\begin{array}{l}15.5 \pm 12.1 \% \%^{7,[c]} \\
K_{i}>100,000 n M(r)^{8,[d]}\end{array}$ & $11 \pm 2 \mu \mathrm{M}$ \\
\hline 7 & $\begin{array}{l}\mathrm{K}_{\mathrm{i}}=130 \mu \mathrm{M}^{5,[\mathrm{a}]} \\
\mathrm{K}_{\mathrm{i}}=83,400 \mathrm{nM}^{7,[\mathrm{c}]} \\
\mathrm{K}_{\mathrm{i}}=105,000 \mathrm{nM}(\mathrm{r})^{8,[\mathrm{~d}]}\end{array}$ & $\begin{array}{l}\mathrm{A}_{2 \mathrm{~A}} \\
\mathrm{~K}_{\mathrm{i}}=187,000 \mathrm{nM}^{7,[\mathrm{c}]} \\
\mathrm{K}_{\mathrm{i}}>250,000 \mathrm{nM}(\mathrm{r})^{8,[\mathrm{~d}]} \\
\mathrm{A}_{2 \mathrm{~B}} \\
\mathrm{~K}_{\mathrm{i}}=130,000 \mathrm{nM}(\mathrm{h})^{8,[\mathrm{~d}]}\end{array}$ & $\begin{array}{l}19.9 \pm 7.1 \% \%^{7,[c]} \\
K_{i}>100,000 \mathrm{nM}(r)^{8,[d]}\end{array}$ & inactive at $100 \mu \mathrm{M}$ \\
\hline 8 & $\begin{array}{l}\mathrm{K}_{\mathrm{i}}=13 \pm 2 \mu \mathrm{M}^{5,[\mathrm{a}]} \\
\mathrm{K}_{\mathrm{i}}=10,700 \mathrm{nM}(\mathrm{h})^{9,[\mathrm{e}]} \\
\mathrm{K}_{\mathrm{i}}=44,900 \mathrm{nM}(\mathrm{h})^{9,[\mathrm{e}]} \\
\mathrm{K}_{\mathrm{i}}=41,000 \mathrm{nM}(\mathrm{r})^{9,[\mathrm{e}]} \\
\mathrm{K}_{\mathrm{i}}=44,000 \mathrm{nM}(\mathrm{r})^{9,[\mathrm{e}]} \\
\mathrm{K}_{\mathrm{i}}=47,000 \mathrm{nM}(\mathrm{gp})^{9,[\mathrm{e}]} \\
\mathrm{K}_{\mathrm{i}}=44,000 \mathrm{nM}(\mathrm{c})^{9,[\mathrm{e}]}\end{array}$ & $\begin{array}{l}\mathrm{A}_{2 \mathrm{~A}} \\
\mathrm{~K}_{\mathrm{i}}=23,400 \mathrm{nM}(\mathrm{h})^{9,[\mathrm{e}]} \\
\mathrm{K}_{\mathrm{i}}=9,560 \mathrm{nM}(\mathrm{h})^{9,[\mathrm{e}]} \\
\mathrm{K}_{\mathrm{i}}=45,000 \mathrm{nM}(\mathrm{r})^{9,[\mathrm{e}]} \\
\mathrm{K}_{\mathrm{i}}=32,500 \mathrm{nM}(\mathrm{r})^{9,[\mathrm{e}]} \\
\mathrm{K}_{\mathrm{i}}=48,000 \mathrm{nM}(\mathrm{r})^{9,[\mathrm{e}]} \\
\mathrm{A}_{2 \mathrm{~B}} \\
\mathrm{~K}_{\mathrm{i}}=33,800 \mathrm{nM}(\mathrm{h})^{9,[\mathrm{e}]} \\
\mathrm{K}_{\mathrm{i}}=10,400 \mathrm{nM}(\mathrm{h})^{9,[\mathrm{e}]} \\
\mathrm{K}_{\mathrm{i}}=20,500 \mathrm{nM}(\mathrm{h})^{9,[\mathrm{e}]} \\
\mathrm{K}_{\mathrm{i}}=30,000 \mathrm{nM}(\mathrm{r})^{9,[\mathrm{e}]} \\
\mathrm{K}_{\mathrm{i}}=13,000 \mathrm{nM}(\mathrm{m})^{9,[\mathrm{e}]}\end{array}$ & $\begin{array}{l}K_{i}=13,300 n M(h)^{9,[e]} \\
K_{i}>100,000 n M(r)^{9,[e]}\end{array}$ & $9 \pm 2 \mu \mathrm{M}$ \\
\hline 9 & inactive $^{10,[f]}$ & n.d. & n.d. & inactive at $100 \mu \mathrm{M}$ \\
\hline 10 & n.d. & n.d. & n.d. & $25 \pm 3 \mu \mathrm{M}$ \\
\hline 11 & $\mathrm{~K}_{\mathrm{i}}=140 \mu \mathrm{M}^{5,[\mathrm{a}]}$ & n.d. & n.d. & $44 \pm 4 \mu \mathrm{M}$ \\
\hline 12 & $\mathrm{~K}_{\mathrm{i}}=60 \mu \mathrm{M}^{5,[a]}$ & n.d. & n.d. & $24 \pm 3 \mu \mathrm{M}$ \\
\hline 13 & $\mathrm{~K}_{\mathrm{i}}=130 \mu \mathrm{M}^{5,[a]}$ & n.d. & n.d. & $6 \pm 3 \mu \mathrm{M}$ \\
\hline 14 & $\begin{array}{l}\mathrm{K}_{\mathrm{i}}=300 \mu \mathrm{M}^{5,[\mathrm{a}]} \\
30.2 \pm 6.7 \% \%^{7,[\mathrm{c}]}\end{array}$ & $\begin{array}{l}\mathrm{A}_{2 \mathrm{~A}} \\
24.7 \pm 3.9 \% 7,[\mathrm{c}]\end{array}$ & $16.8 \pm 9.5 \%{ }^{7,[c]}$ & $17 \pm 3 \mu \mathrm{M}$ \\
\hline 15 & $\mathrm{IC}_{50}=0.40 \pm 0.15 \mu \mathrm{M}^{11,[\mathrm{~g}]}$ & $\mathrm{IC}_{50}=0.55 \pm 0.04 \mu \mathrm{M}^{11,[\mathrm{~g}]}$ & $12.0 \pm 6.0 \% \%^{7,[c]}$ & $0.5 \pm 0.3 \mu \mathrm{M}$ \\
\hline
\end{tabular}




\begin{tabular}{|c|c|c|c|c|}
\hline ID & $A_{1}$ & $A_{2}$ & $A_{3}$ & ${ }^{\prime} C_{50}(T L X)$ \\
\hline & $\begin{array}{l}\mathrm{K}_{\mathrm{i}}=86.0 \pm 2.8 \mathrm{nM}^{12,[\mathrm{~h}]} \\
\mathrm{K}_{\mathrm{i}}=1.2 \mathrm{nM}^{13,[\mathrm{i}]} \\
\mathrm{K}_{\mathrm{i}}=86 \mathrm{nM}^{7,[\mathrm{c}]}\end{array}$ & $\begin{array}{l}\mathrm{K}_{i}=848 \pm 115 \mathrm{nM}^{12,[\mathrm{~h}]} \\
\mathrm{A}_{2 \mathrm{~A}} \\
\mathrm{~K}_{\mathrm{i}}=850 \mathrm{nM}^{7,[\mathrm{c}]}\end{array}$ & & \\
\hline 16 & $\begin{array}{l}\mathrm{IC}_{50}=6.50 \mathrm{nM}^{14,[i]} \\
\mathrm{K}_{\mathrm{i}}=3.6 \mathrm{nM}^{13,[\mathrm{i}]}\end{array}$ & n.d. & n.d. & $0.7 \pm 0.2 \mu \mathrm{M}$ \\
\hline 17 & $\begin{array}{l}\mathrm{IC}_{50}=13 \mathrm{nM}^{14,[i]} \\
\mathrm{K}_{\mathrm{i}}=5.4 \mathrm{nM}^{13,[\mathrm{i}]}\end{array}$ & n.d. & n.d. & $0.5 \pm 0.2 \mu \mathrm{M}$ \\
\hline 18 & $\begin{array}{l}\mathrm{K}_{\mathrm{i}}=0.14 \pm 0.01 \mu \mathrm{M}^{5,[a]} \\
\mathrm{IC}_{50}=0.80 \mathrm{nM}^{14,[i]} \\
\mathrm{K}_{\mathrm{i}}=0.51 \mathrm{nM}^{13,[\mathrm{i}]}\end{array}$ & n.d. & n.d. & $7 \pm 4 \mu \mathrm{M}$ \\
\hline 19 & inactive at $21 \mu \mathrm{M}^{13,[i]}$ & n.d. & n.d. & $0.5 \pm 0.3 \mu \mathrm{M}$ \\
\hline 20 & inactive at $21 \mu \mathrm{M}^{13,[i]}$ & n.d. & n.d. & $0.23 \pm 0.08 \mu \mathrm{M}$ \\
\hline 21 & $\begin{array}{l}\mathrm{K}_{\mathrm{i}}=0.068 \pm 0.021 \mu \mathrm{M}^{5,[a]} \\
\mathrm{I}_{50}=0.80 \mathrm{nM}^{14,[i]} \\
\mathrm{K}_{\mathrm{i}}=0.64 \mathrm{nM}^{13,[i]}\end{array}$ & n.d. & n.d. & $0.34 \pm 0.07 \mu \mathrm{M}$ \\
\hline 22 & $\begin{array}{l}\mathrm{IC}_{50}=350 \mathrm{nM}^{14,[i]} \\
\mathrm{K}_{\mathrm{i}}=190 \mathrm{nM}^{13,[i]}\end{array}$ & n.d. & n.d. & $<1.5$ fold repression \\
\hline 23 & $\begin{array}{l}\mathrm{IC}_{50}=20 \mathrm{nM}^{14,[i]} \\
\mathrm{K}_{\mathrm{i}}=8.7 \mathrm{nM}^{13,[\mathrm{i}]}\end{array}$ & n.d. & n.d. & $0.3 \pm 0.1 \mu \mathrm{M}$ \\
\hline 24 & $\begin{array}{l}\mathrm{K}_{\mathrm{i}}=0.12 \pm 0.03 \mu \mathrm{M}^{5,[\mathrm{a}]} \\
\mathrm{IC}_{50}=1.5 \mathrm{nM}^{14,[\mathrm{i}]} \\
\mathrm{K}_{\mathrm{i}}=0.63 \mathrm{nM}^{13,[\mathrm{i}]}\end{array}$ & n.d. & n.d. & $4 \pm 2 \mu \mathrm{M}$ \\
\hline 25 & n.d. & n.d. & n.d. & $1.8 \pm 0.6 \mu \mathrm{M}$ \\
\hline 26 & n.d. & n.d. & n.d. & $<1.5$ fold repression \\
\hline 27 & $\mathrm{IC}_{50}=3.50 \mathrm{nM}^{14,[j]}$ & n.d. & n.d. & $7 \pm 4 \mu \mathrm{M}$ \\
\hline 28 & $\mathrm{~K}_{\mathrm{i}}=350 \pm 20 \mathrm{nM}^{12,[\mathrm{~h}]}$ & $\mathrm{K}_{\mathrm{i}}=2,780 \pm 50 \mathrm{nM}^{12,[\mathrm{~h}]}$ & n.d. & $0.2 \pm 0.1 \mu \mathrm{M}$ \\
\hline 29 & $\mathrm{~K}_{\mathrm{i}}=72.4 \pm 3.7 \mathrm{nM}^{12,[\mathrm{~h}]}$ & $\mathrm{K}_{\mathrm{i}}=984 \pm 70 \mathrm{nM}^{12,[\mathrm{~h}]}$ & n.d. & $0.16 \pm 0.02 \mu \mathrm{M}$ \\
\hline 30 & $\begin{array}{l}\mathrm{K}_{\mathrm{i}}=841 \mathrm{nM}^{9,[\mathrm{e}]} \\
\mathrm{K}_{\mathrm{i}}=230 \mathrm{nM}(\mathrm{r})^{8,[\mathrm{~d}]}\end{array}$ & $\begin{array}{l}\mathrm{A}_{2 \mathrm{~A}} \\
\mathrm{~K}_{\mathrm{i}}=12 \mathrm{nM}(\mathrm{h})^{9,[\mathrm{e}]} \\
\mathrm{K}_{\mathrm{i}}=91.2 \mathrm{nM}(\mathrm{h})^{8,[\mathrm{~d}]} \\
\mathrm{K}_{\mathrm{i}}=2.2 \mathrm{nM}(\mathrm{r})^{8,[\mathrm{~d}]} \\
\mathrm{K}_{\mathrm{i}}=4.46 \mathrm{nM}(\mathrm{r})^{8,[\mathrm{~d}]} \\
\mathrm{A}_{2 \mathrm{~B}} \\
\mathrm{~K}_{\mathrm{i}}>10,000^{9,[\mathrm{e}]}\end{array}$ & $\mathrm{K}_{\mathrm{i}}=4,470 \mathrm{nM}^{9,[\mathrm{e}]}$ & $0.04 \pm 0.01 \mu \mathrm{M}$ \\
\hline 31 & $\mathrm{~K}_{\mathrm{i}}=5,340 \pm 1,440 \mathrm{nM}^{15,[\mathrm{k}]}$ & $\mathrm{K}_{\mathrm{i}}=1,100 \pm 250 \mathrm{nM}^{15,[\mathrm{k}]}$ & n.d. & $0.19 \pm 0.06 \mu \mathrm{M}$ \\
\hline
\end{tabular}

[a] $K_{i}$ values for $A_{1}$ receptors were obtained from antagonism of cAMP levels induced by $10 \mu \mathrm{M}$ adenosine in human fetal lung fibroblasts.

[b] $\quad K_{i}$ values for $A_{1}$ receptors were obtained from inhibition of $1 \mathrm{nM}\left[{ }^{3} \mathrm{H}\right]-N^{6}$-(phenylisopropyl)adenosine (PIA) binding to rat brain membranes. $K_{i}$ values for $A_{2}$ receptors were obtained from inhibition of 5 '- $N$-ethylcarboxamidoadenosine (NECA)elicited stimulation of adenylate cyclase in human platelet membranes.

[c] $\mathrm{K}_{\mathrm{i}}$ values or percent displacement at a concentration of $100 \mu \mathrm{M}$ for $\mathrm{A}_{1}$ receptors were obtained from displacement of $\left[{ }^{3} \mathrm{H}\right] \mathrm{PIA}$ (or $\left[{ }^{3} \mathrm{H}\right]-N^{6}$-cyclohexyladenosine $(\mathrm{CHA})$ ) binding from rat brain membranes, for $\mathrm{A}_{2}$ receptors from displacement of $\left[{ }^{3} \mathrm{H}\right]-2-\left[4-(2-c a r b o x y e t h y l)\right.$ phenyl] ${ }^{2}$ thylamino-5'- $N$-ethlcarboxamidoadenosine (CGS 21680) (or [ $\left.{ }^{3} \mathrm{H}\right]-\mathrm{NECA}$ in the presence of $50 \mathrm{nM} \mathrm{CPA}$ ) from rat striatal membranes, for $\mathrm{A}_{3}$ receptors from displacement of $\left[{ }^{125} \mathrm{I}\right]-N^{6}-2-(4-$ aminophenyl)ethyladenosine (APNEA) binding from membranes of $\mathrm{CHO}$ cells stably transfected with the rat $\mathrm{A}_{3}-\mathrm{cDNA}$.

[d] $K_{i}$ values were probably obtained from radioligand studies in respective species.

[e] $K_{i}$ values were probably obtained from radioligand studies in respective species.

[f] Activity for $A_{1}$ receptors was obtained from inhibition of $\left[{ }^{3} \mathrm{H}\right]-\mathrm{CHA}$ using homogenates of adult rat forebrains.

[g] $\quad \mathrm{IC}_{50}$ values for $\mathrm{A}_{1}$ receptors were obtained from antagonism of binding of $1 \mathrm{nM}\left[{ }^{3} \mathrm{H}\right]-\mathrm{CHA}$ to rat cerebral cortical membranes. $I C_{50}$ values for $A_{2}$ receptors were obtained from antagonism of cyclic $\left[{ }^{3} \mathrm{H}\right]$-adenosine monophosphate (AMP) accumulation elicited by $15 \mu \mathrm{M}$ 2-chloroadenosine in $\left[{ }^{3} \mathrm{H}\right]$-adenine-labeled guinea pig cerebral cortical slices.

[h] $K_{i}$ values for $A_{1}$ receptors were obtained from inhibition of binding of $\left[{ }^{3} \mathrm{H}\right]-\mathrm{PIA}$ in rat cortical membranes. $K_{i}$ values for $A_{2}$ receptors were obtained from inhibition of $\left[{ }^{3} \mathrm{H}\right]-\mathrm{NECA}$ in rat striatal membranes.

[i] $K_{i}$ values for $A_{1}$ receptors were obtained from inhibition of binding of $\left[{ }^{3} \mathrm{H}\right]-\mathrm{CHA}$ in bovine brain membranes.

[j] $I_{50}$ values for $A_{1}$ receptors were obtained from inhibition of $\left[{ }^{3} \mathrm{H}\right]-\mathrm{CHA}$ in bovine brain membranes.

$[\mathrm{k}] \quad \mathrm{K}_{\mathrm{i}}$ values for $A_{1}$ receptors were obtained from inhibition of $1 \mathrm{nM}\left[{ }^{3} \mathrm{H}\right]$-PIA at rat receptors. $K_{i}$ values for $A_{2}$ receptors were obtained from inhibition of $5 \mathrm{nM}\left[{ }^{3} \mathrm{H}\right]$-CGS 21680 at rat striatal receptors. 
A
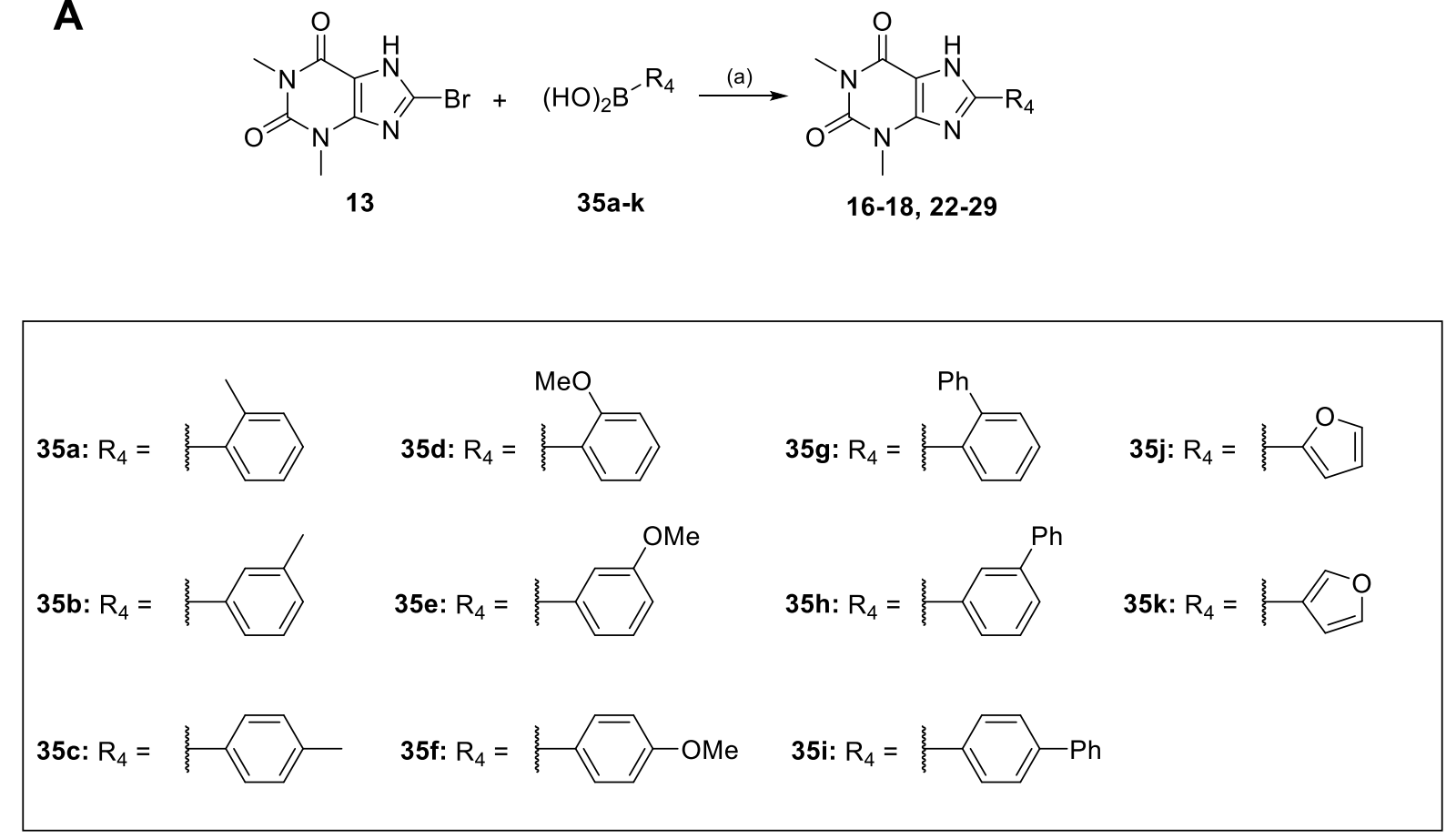

B<smiles>[R4]C(=O)NC1=C(N)N([R3])C(=O)N([R])C(=O)N1[R]</smiles>

36a: $R_{1}=R_{3}=M e$

37a-f

38a-f

19-21, 31-32, 34

36b: $R_{1}=R_{3}=n$-propyl<smiles>[R16]=C(C)c1ccccc1Cl</smiles><smiles></smiles>

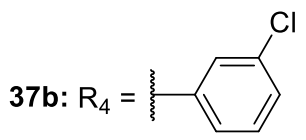<smiles></smiles>

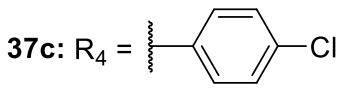

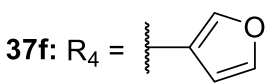

Scheme S1. Synthesis of xanthine derivatives 16-18 and 22-29 (A) and 19-21, 31-32 and 34 (B). Reagents \& conditions: A (a) dioxane/ $\mathrm{H}_{2} \mathrm{O}(4: 1), \mathrm{Na}_{2} \mathrm{CO}_{3}, \mathrm{Pd}\left(\mathrm{PPh}_{3}\right)_{4}, 110^{\circ} \mathrm{C}, 4-7 \mathrm{~h}$, yields $10-58 \%$; $\mathbf{B}$ (a) $\mathrm{CHCl}_{3}, \mathrm{EDC} \cdot \mathrm{HCl}, \mathrm{RT}-50^{\circ} \mathrm{C}, 2-72 \mathrm{~h}$, yields $52-83 \%$; (b) $\mathrm{H}_{2} \mathrm{O}$ or DMSO, $\mathrm{NaOH}, 100^{\circ} \mathrm{C}, 2-3 \mathrm{~h}$, yields $24-81 \%$ 


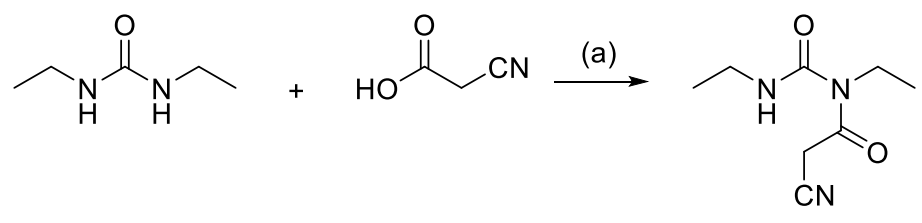

39<smiles>CCn1c(N)cc(=O)n(CC)c1=O</smiles>

42<smiles>CCn1c(N)c([N+](=O)[O-])c(=O)n(CC)c1=O</smiles>

33

Scheme S2. Synthesis of xanthine derivative $3^{16,17}$. Reagents and conditions: (a) acetic anhydride, $80^{\circ} \mathrm{C}$, 2 hours, yield $53 \%$; (b) $\mathrm{H}_{2} \mathrm{O}, \mathrm{NaOH}, 80^{\circ} \mathrm{C}$, 2 hours, yield $50 \%$; (c) $\mathrm{H}_{2} \mathrm{O} / \mathrm{AcOH}$ (1:1), $\mathrm{NaNO}_{2}$, $60^{\circ} \mathrm{C}$, 2 hours, yield $52 \%$; (d) $\mathrm{CHCl}_{3}$, 3-Furoic acid, RT, 23 hours, yield $49 \%$; (e) $\mathrm{H}_{2} \mathrm{O} / \mathrm{NH}_{3}(12.5 \%$ ), $\mathrm{Na}_{2} \mathrm{~S}_{2} \mathrm{O}_{4}, 80^{\circ} \mathrm{C}, 4$ hours; (f) $\mathrm{NaOH}, 100^{\circ} \mathrm{C}, 3$ hours, yield $7 \%$. 


\section{Supplementary Methods}

Chemistry. General. All chemicals and solvents were purchased from commercial sources and used without any further purification. Reactions were monitored by thin layer chromatography (TLC) using TLC-plates (silica gel 60 F254, 0.2 mm, Merck or Alugram Xtra Sil G/UV $0.2 \mathrm{~mm}$, Macherey Nagel). Detection occurred under UV-light $(\lambda=254 \mathrm{~nm}$ and 366 $\mathrm{nm}$ ). NMR spectra were measured in DMSO- $d 6$ or in $\mathrm{CDCl}_{3}$ on Bruker (Billerica, MA, U.S.A ) instruments DPX $250(250 \mathrm{MHz})$, Bruker AVANCE $300(300 \mathrm{MHz})$ and Bruker AVANCE 500 $(500 \mathrm{MHz})$. Tetramethylsilane (TMS) was used as internal standard. The chemical shift $\delta$ is reported as ppm and coupling constants $\mathrm{J}$ in $\mathrm{Hz}$. Multiplicities of signals are abbreviated as $\mathrm{S}$ for singulet, bs for broad singulett, $\mathrm{d}$ for duplet, $\mathrm{t}$ for triplett and $\mathrm{m}$ for mulitplett. Electro spray ionization mass spectrometry (ESI-MS) was performed on Surveyor MSQ spectrometer (ThermoFisher) whereas high resolution mass spectrometry (HR-MS) was performed on a MALDI LTQ Orbitrap XL (ThermoFisher). The purity of synthesized compounds 16-29,31,32 was determined by HPLC on a Waters RP-HPLC running a gradient $\left(40 \% \mathrm{MeOH}+60 \% \mathrm{H}_{2} \mathrm{O}\right.$ $+0.1 \%$ formic acid for 5 minutes, then for the next 20 minutes up to only $100 \% \mathrm{MeOH}+0.1$ formic acid and the last 20 minutes maintained $100 \% \mathrm{MeOH}+0.1$ formic acid) on a MultoHigh100 RP18-5 $\mu \mathrm{m}, 240 * 4 \mathrm{~mm}$ column with a flow rate of $1 \mathrm{~mL} / \mathrm{min}$ with UV-detection at $\lambda=254 \mathrm{~nm}$ and $280 \mathrm{~nm}$. All synthesized compound $(16-29,31,32)$ for in vitro characterization had a purity $\geq 95 \%$.

General procedure for Suzuki coupling reaction. 13 (1.00 eq), the corresponding boronic acid (35a-k, 1.20 eq), $\mathrm{Na}_{2} \mathrm{CO}_{3}$ (3.00 eq) and $\mathrm{Pd}\left(\mathrm{PPh}_{3}\right)_{4}(0.05 \mathrm{eq})$ were suspended in a degassed 4:1 mixture of dioxane $/ \mathrm{H}_{2} \mathrm{O}(10 \mathrm{~mL})$ under inert atmosphere using argon. The suspension was stirred at $110^{\circ} \mathrm{C}$ for $4-7 \mathrm{~h}$. Reaction progress was monitored by TLC and the reaction was stopped after full consumption of the boronic acid component. After cooling to room temperature, aqueous hydrochloric acid solution ( $5 \% \mathrm{v} / \mathrm{v})$ was added and the aqueous layer was extracted with chloroform, methylene chloride or ethyl acetate until the product had been completely extracted into the organic layer which was monitored by TLC. 23, 26 and 27 precipitated from the extraction solution, were filtered of and dried in vacuo. For 16-18 and 22 , 24, 25 and 28-29 the combined organic layers were dried over $\mathrm{Na}_{2} \mathrm{SO}_{4}$ and the solvents were evaporated under reduced pressure. The crude products were recrystallized from acetone.

General procedure for cyclization of 5,6-diamino-1,3-dimethylpyrimidine-2,4(1H,3H)-dione with arylcarboxylates. $36 \mathrm{a}$ or $\mathbf{3 6 b}$ (1.00 eq), the corresponding arylcarboxylate $37 \mathrm{a}-\mathrm{f}(1.10 \mathrm{eq})$ and $\mathrm{EDC} \cdot \mathrm{HCl}(1.20 \mathrm{eq})$ were suspended in dry chloroform and stirred at room temperature or $50{ }^{\circ} \mathrm{C}$. Reaction progress was monitored by TLC and the reaction was stopped after full consumption of the diamine component. After cooling to room temperature, the precipitate was 
collected by filtration and washed with hot water (38a-d, 38f). In case of $38 \mathrm{e}$ the crude product was extracted with chloroform. The organic phases were dried over $\mathrm{Na}_{2} \mathrm{SO}_{4}$ and the solvent was removed under reduced pressure. The crude product was resuspended in water, filtered and washed with hot water. Amides (38a-f, $1.00 \mathrm{eq})$ and $\mathrm{NaOH}(10 \mathrm{eq})$ were suspended in water or DMSO and the suspension was stirred at $100{ }^{\circ} \mathrm{C}$ until the solids were completely dissolved. After cooling to room temperature, aqueous hydrochloric acid solution ( $5 \% \mathrm{v} / \mathrm{v})$ was added which led to formation of a precipitate. The suspension was stirred for further $30 \mathrm{~min}$ at room temperature and the precipitate was collected by filtration. The precipitate was washed with hot water or acetone and dried in vacuo or recrystallized from methylene chloride/methanol. In case of 32 after addition of aqueous hydrochloric acid solution ( $5 \% \mathrm{v} / \mathrm{v})$ the aqueous layer was extracted with ethyl acetate. The combined organic layer was dried over $\mathrm{Na}_{2} \mathrm{SO}_{4}$ and the solvent was removed under reduced pressure. The product was dried in vacuo.

1,3-Dimethyl-8-(o-tolyl)-3,7-dihydro-1H-purine-2,6-dione (16). 16 was prepared according to the general procedure for Suzuki coupling reaction using 8-bromotheophylline $(\mathbf{1 3}, 200 \mathrm{mg}$, $0.772 \mathrm{mmol}, 1.00 \mathrm{eq}$ ), $\mathrm{Na}_{2} \mathrm{CO}_{3}$ (246 mg, $2.32 \mathrm{mmol}, 3.00 \mathrm{eq}$ ), o-tolylboronic acid (35a, 126 $\mathrm{mg}, 0.926 \mathrm{mmol}, 1.20 \mathrm{eq})$ and $\mathrm{Pd}\left(\mathrm{PPh}_{3}\right)_{4}(45 \mathrm{mg}, 0.039 \mathrm{mmol}, 0.05 \mathrm{eq})$ suspended in a $10 \mathrm{~mL}$ degassed dioxane $/ \mathrm{H}_{2} \mathrm{O}$ mixture under argon atmosphere. The product was obtained as a colorless solid (47 mg, 22\%). $\mathrm{R}_{\mathrm{f}}=0.7$ (2:1 ethyl acetate/ $n$-hexane). ${ }^{1} \mathrm{H}-\mathrm{NMR}$ (500 MHz, DMSO$\left.d_{6}\right): \delta=13.58(\mathrm{~s}, 1 \mathrm{H}), 7.67(\mathrm{dd}, J=7.8,0.8 \mathrm{~Hz}, 1 \mathrm{H}), 7.41-7.30(\mathrm{~m}, 3 \mathrm{H}), 3.49(\mathrm{~s}, 3 \mathrm{H}), 3.27(\mathrm{~s}$, $3 \mathrm{H}), 2.54(\mathrm{~s}, 3 \mathrm{H}) \mathrm{ppm} .{ }^{13} \mathrm{C}-\mathrm{NMR}\left(126 \mathrm{MHz}, \mathrm{DMSO}-\mathrm{d}_{6}\right): \delta=154.27,151.19,150.59,148.14$, 137.02, 131.23, 129.81, 129.44, 128.58, 125.95, 107.09, 29.76, 27.80, 20.76 ppm. MS (ESI+): $\mathrm{m} / \mathrm{z}$ calculated for $\mathrm{C}_{14} \mathrm{H}_{15} \mathrm{~N}_{4} \mathrm{O}_{2}\left([\mathrm{M}+\mathrm{H}]^{+}\right)$271.11, found 271.12. HRMS (MALDI): $\mathrm{m} / z$ calculated for $\mathrm{C}_{14} \mathrm{H}_{15} \mathrm{~N}_{4} \mathrm{O}_{2}\left([\mathrm{M}+\mathrm{H}]^{+}\right)$271.11895, found 271.11913.

1,3-Dimethyl-8-(m-tolyl)-3,7-dihydro-1H-purine-2,6-dione (17). 17 was prepared according to the general procedure for Suzuki coupling reaction using 8-bromotheophylline $(\mathbf{1 3}, 300 \mathrm{mg}$, $1.16 \mathrm{mmol}, 1.00 \mathrm{eq}$ ), $\mathrm{Na}_{2} \mathrm{CO}_{3}$ (368 mg, $3.47 \mathrm{mmol}, 3.00 \mathrm{eq}$ ), $m$-tolylboronic acid (35b, $189 \mathrm{mg}$, $1.39 \mathrm{mmol}, 1.20 \mathrm{eq})$ and $\mathrm{Pd}\left(\mathrm{PPh}_{3}\right)_{4}(67 \mathrm{mg}, 0.057 \mathrm{mmol}, 0.05 \mathrm{eq})$ suspended in a $10 \mathrm{~mL}$ degassed dioxane $/ \mathrm{H}_{2} \mathrm{O}$ mixture under argon atmosphere. The product was obtained as a colorless solid $(115 \mathrm{mg}, 37 \%) . \mathrm{R}_{\mathrm{f}}=0.5$ (2:1 ethyl acetate/n-hexane). ${ }^{1} \mathrm{H}-\mathrm{NMR}(500 \mathrm{MHz}$, DMSO-d $\left.\mathrm{d}_{6}\right) \delta=13.78(\mathrm{~s}, 1 \mathrm{H}), 7.98(\mathrm{~s}, 1 \mathrm{H}), 7.93(\mathrm{~d}, J=7.8 \mathrm{~Hz}, 1 \mathrm{H}), 7.39(\mathrm{t}, J=7.7 \mathrm{~Hz}, 1 \mathrm{H})$, $7.29(\mathrm{~d}, J=7.6 \mathrm{~Hz}, 1 \mathrm{H}), 3.50(\mathrm{~s}, 3 \mathrm{H}), 3.26(\mathrm{~s}, 3 \mathrm{H}), 2.37$ (s, 3H) ppm. ${ }^{13} \mathrm{C}-\mathrm{NMR}(126 \mathrm{MHz}$, DMSO-d $\left.d_{6}\right) \delta=154.17,151.17,149.77,148.44,138.20,130.83,128.83,128.59,126.89$, 123.47, 107.59, 29.76, 27.79, 20.99 ppm. MS (ESI+): $\mathrm{m} / \mathrm{z}$ calculated for $\mathrm{C}_{14} \mathrm{H}_{15} \mathrm{~N}_{4} \mathrm{O}_{2}\left([\mathrm{M}+\mathrm{H}]^{+}\right)$ 271.11, found 271.12. HRMS (MALDI): $\mathrm{m} / z$ calculated for $\mathrm{C}_{14} \mathrm{H}_{15} \mathrm{~N}_{4} \mathrm{O}_{2}\left([\mathrm{M}+\mathrm{H}]^{+}\right) 271.11895$, found 271.11931 . 
1,3-Dimethyl-8-(p-tolyl)-3,7-dihydro-1H-purine-2,6-dione (18). 18 was prepared according to the general procedure for Suzuki coupling reaction using 8-bromotheophylline $(\mathbf{1 3}, 200 \mathrm{mg}$, $0.772 \mathrm{mmol}, 1.00 \mathrm{eq}$ ), $\mathrm{Na}_{2} \mathrm{CO}_{3}$ (246 mg, $2.32 \mathrm{mmol}, 3.00 \mathrm{eq}$ ), p-tolylboronic acid (35c, 126 $\mathrm{mg}, 0.926 \mathrm{mmol}, 1.20 \mathrm{eq})$ and $\mathrm{Pd}\left(\mathrm{PPh}_{3}\right)_{4}(45 \mathrm{mg}, 0.039 \mathrm{mmol}, 0.05 \mathrm{eq})$ suspended in a $10 \mathrm{~mL}$ degassed dioxane $/ \mathrm{H}_{2} \mathrm{O}$ mixture under argon atmosphere. The product was obtained as a colorless solid (92 mg, 44\%). $\mathrm{R}_{\mathrm{f}}=0.7$ (1:1 ethyl acetate/ $n$-hexane). ${ }^{1} \mathrm{H}-\mathrm{NMR}$ (500 MHz, DMSO$\left.\mathrm{d}_{6}\right) \delta=13.75(\mathrm{~s}, 1 \mathrm{H}), 8.03(\mathrm{~d}, J=8.2 \mathrm{~Hz}, 2 \mathrm{H}), 7.32(\mathrm{~d}, J=8.4 \mathrm{~Hz}, 2 \mathrm{H}), 3.50(\mathrm{~s}, 3 \mathrm{H}), 3.27(\mathrm{~s}$, $3 \mathrm{H}), 2.36(\mathrm{~s}, 3 \mathrm{H}) \mathrm{ppm} .{ }^{13} \mathrm{C}-\mathrm{NMR}\left(126 \mathrm{MHz}, \mathrm{DMSO}-\mathrm{d}_{6}\right) \delta=154.19,151.23,149.95,148.55$, $140.11,129.55,126.36,126.02,107.47,29.79,27.82,21.01$ ppm. MS (ESI+): m/z calculated for $\mathrm{C}_{14} \mathrm{H}_{15} \mathrm{~N}_{4} \mathrm{O}_{2}\left([\mathrm{M}+\mathrm{H}]^{+}\right)$271.11, found 271.08. HRMS (MALDI): $m / z$ calculated for $\mathrm{C}_{14} \mathrm{H}_{15} \mathrm{~N}_{4} \mathrm{O}_{2}$ $\left([\mathrm{M}+\mathrm{H}]^{+}\right)$271.11895, found 271.11942.

8-(2-Chlorophenyl)-1,3-dimethyl-3,7-dihydro-1H-purine-2,6-dione (19). $\quad N$-(6-amino-1,3dimethyl-2,4-dioxo-1,2,3,4-tetrahydropyrimidin-5-yl)-2-chlorobenzamide (38a, $116 \mathrm{mg}, 0.376$ mmol, $1.00 \mathrm{eq}$ ) was suspended in $15 \mathrm{~mL} \mathrm{H} \mathrm{H}_{2} \mathrm{O}$. NaOH (150 mg, $3.76 \mathrm{mmol}, 10.0 \mathrm{eq}$ ) were added to the previous suspension. The suspension was stirred at $100^{\circ} \mathrm{C}$ for 3 hours until complete dissolution of the solids. After cooling to room temperature, $30 \mathrm{~mL}$ aqueous $\mathrm{HCl}(5 \%$ $\mathrm{v} / \mathrm{v}$ ) solution was added which caused precipitation of a solid. The resulting suspension was stirred for 30 minutes at room temperature. The precipitate was filtered off and washed with hot water. The product was obtained as a colorless solid (47 mg, 43\%). $R_{f}=0.8$ (3:1 ethyl acetate/n-hexane). ${ }^{1} \mathrm{H}-\mathrm{NMR}\left(500 \mathrm{MHz}\right.$, DMSO- $\left.\mathrm{d}_{6}\right) \delta=13.80(\mathrm{~s}, 1 \mathrm{H}), 7.72$ (dd, J = 7.6, $1.8 \mathrm{~Hz}$, $1 \mathrm{H}), 7.63(\mathrm{dd}, \mathrm{J}=8.0,1.3 \mathrm{~Hz}, 1 \mathrm{H}), 7.55(\mathrm{td}, \mathrm{J}=7.7,1.8 \mathrm{~Hz}, 1 \mathrm{H}), 7.49(\mathrm{td}, \mathrm{J}=7.5,1.3 \mathrm{~Hz}, 1 \mathrm{H}$ ), 3.48 (s, 3H), 3.27 (s, 3H). ppm. ${ }^{13} \mathrm{C}-\mathrm{NMR}\left(126 \mathrm{MHz}, \mathrm{DMSO}-\mathrm{d}_{6}\right) \delta=154.31,151.15,148.01$, 147.66, 132.00, 131.92, 131.63, 130.30, 128.65, 127.36, 107.63, 29.82, 27.82 ppm. MS $(\mathrm{ESI}+): \mathrm{m} / z$ calculated for $\mathrm{C}_{13} \mathrm{H}_{12} \mathrm{CIN}_{4} \mathrm{O}_{2}\left([\mathrm{M}+\mathrm{H}]^{+}\right)$291.06, found 291.11. HRMS (MALDI): $\mathrm{m} / \mathrm{z}$ calculated for $\mathrm{C}_{13} \mathrm{H}_{12} \mathrm{CIN}_{4} \mathrm{O}_{2}\left([\mathrm{M}+\mathrm{H}]^{+}\right)$291.06433, found 291.06444.

8-(3-Chlorophenyl)-1,3-dimethyl-3,7-dihydro-1H-purine-2,6-dione $\quad$ (20). $\quad \mathrm{N}$-(6-amino-1,3dimethyl-2,4-dioxo-1,2,3,4-tetrahydropyrimidin-5-yl)-3-chlorobenzamide (38b, $139 \mathrm{mg}, 0.450$ mmol, 1.00 eq) was suspended in $20 \mathrm{~mL} \mathrm{H}$. $\mathrm{NaOH}$ (180 mg, $4.50 \mathrm{mmol}, 10.0 \mathrm{eq}$ ) were added to the previous suspension. The suspension was stirred at $100^{\circ} \mathrm{C}$ for 2 hours until complete dissolution of the solids. After cooling to room temperature, $30 \mathrm{~mL}$ aqueous $\mathrm{HCl}(5 \%$ $\mathrm{v} / \mathrm{v}$ ) solution was added which caused precipitation of a solid. The resulting suspension was stirred for 30 minutes at room temperature. The precipitate was filtered off and washed with hot water. The product was obtained as a colorless solid (78 mg, 59\%). $R_{f}=0.7$ (3:1 ethyl acetate/ $n$-hexane). ${ }^{1} \mathrm{H}$-NMR $(500 \mathrm{MHz}$, DMSO-d 6 ) $\delta=14.00(\mathrm{~s}, 1 \mathrm{H}), 8.21-8.17(\mathrm{~m}, 1 \mathrm{H}), 8.12$ $-8.07(\mathrm{~m}, 1 \mathrm{H}), 7.58-7.52(\mathrm{~m}, 2 \mathrm{H}), 3.50(\mathrm{~s}, 3 \mathrm{H}), 3.27(\mathrm{~s}, 3 \mathrm{H})$ ppm. ${ }^{13} \mathrm{C}-\mathrm{NMR}(126 \mathrm{MHz}$, DMSO$\left.d_{6}\right) \delta=154.26,151.15,148.33,147.95,133.78,130.96,130.66,129.88,125.87,124.88$, 
108.13, 29.78, 27.83 ppm. MS (ESI+): $m / z$ calculated for $\mathrm{C}_{13} \mathrm{H}_{10} \mathrm{CIN}_{4} \mathrm{O}_{2}\left([\mathrm{M}-\mathrm{H}]^{-}\right)$289.03, found 289.03. HRMS (MALDI): $m / z$ calculated for $\mathrm{C}_{13} \mathrm{H}_{12} \mathrm{CIN}_{4} \mathrm{O}_{2}\left([\mathrm{M}+\mathrm{H}]^{+}\right)$291.06433, found 291.06419.

8-(4-Chlorophenyl)-1,3-dimethyl-3,7-dihydro-1H-purine-2,6-dione $\quad$ (21). $\quad N$-(6-amino-1,3dimethyl-2,4-dioxo-1,2,3,4-tetrahydropyrimidin-5-yl)-4-chlorobenzamide (38c, $148 \mathrm{mg}, 0.478$ mmol, 1.00 eq) was suspended in $20 \mathrm{~mL} \mathrm{H} \mathrm{H}_{2} \mathrm{O}$. NaOH (191 mg, $4.78 \mathrm{mmol}, 10.0 \mathrm{eq}$ ) were added to the previous suspension. The suspension was stirred at $100^{\circ} \mathrm{C}$ for 3 hours until complete dissolution of the solids. After cooling to room temperature, $30 \mathrm{~mL}$ aqueous $\mathrm{HCl}(5 \%$ $\mathrm{v} / \mathrm{v}$ ) solution was added which caused precipitation of a solid. The resulting suspension was stirred for 30 minutes at room temperature. The precipitate was filtered off and washed with hot water. After recrystallization in methylene chloride/methanol the product was obtained as a colorless solid (53 mg, 38\%). $\mathrm{R}_{\mathrm{f}}=0.6$ (3:1 ethyl acetate/ $n$-hexane). ${ }^{1} \mathrm{H}-\mathrm{NMR}(500 \mathrm{MHz}$, DMSO- $\left.\mathrm{d}_{6}\right) \delta=13.95(\mathrm{~s}, 1 \mathrm{H}), 8.18-8.12(\mathrm{~m}, 2 \mathrm{H}), 7.63-7.57(\mathrm{~m}, 2 \mathrm{H}), 3.51(\mathrm{~s}, 3 \mathrm{H}), 3.27(\mathrm{~s}$, $3 \mathrm{H})$ ppm. ${ }^{13} \mathrm{C}-\mathrm{NMR}\left(126 \mathrm{MHz}\right.$, DMSO-d $\left.\mathrm{d}_{6}\right) \delta=154.27,151.18,148.55,148.46,134.83,129.09$, 128.06, 127.65, 108.00, 29.78, 27.82 ppm. MS (ESI+): $\mathrm{m} / \mathrm{z}$ calculated for $\mathrm{C}_{13} \mathrm{H}_{12} \mathrm{CIN}_{4} \mathrm{O}_{2}$ $\left([\mathrm{M}+\mathrm{H}]^{+}\right)$291.06, found 291.14. HRMS (MALDI): $\mathrm{m} / \mathrm{z}$ calculated for $\mathrm{C}_{13} \mathrm{H}_{12} \mathrm{CIN}_{4} \mathrm{O}_{2}\left([\mathrm{M}+\mathrm{H}]^{+}\right)$ 291.06433 , found 291.06451.

8-(2-Methoxyphenyl)-1,3-dimethyl-3,7-dihydro-1H-purine-2,6-dione (22). 22 was prepared according to the general procedure for Suzuki coupling reaction using 8-bromotheophylline (13, $200 \mathrm{mg}, 0.772 \mathrm{mmol}, 1.00 \mathrm{eq}), \mathrm{Na}_{2} \mathrm{CO}_{3}$ (246 mg, $2.32 \mathrm{mmol}, 3.00 \mathrm{eq}$ ), 2methoxyphenylboronic acid (35d, $141 \mathrm{mg}, 0.926 \mathrm{mmol}, 1.20 \mathrm{eq})$ and $\mathrm{Pd}\left(\mathrm{PPh}_{3}\right)_{4}(45 \mathrm{mg}, 0.039$ mmol, 0.05 eq) suspended in a $10 \mathrm{~mL}$ degassed dioxane $/ \mathrm{H}_{2} \mathrm{O}$ mixture under argon atmosphere. The product was obtained as a colorless solid (129 mg, 58\%). $R_{f}=0.4$ (2:1 ethyl acetate/n-hexane). ${ }^{1} \mathrm{H}-\mathrm{NMR}\left(500 \mathrm{MHz}, \mathrm{CDCl}_{3}\right) \delta=10.97(\mathrm{~s}, 1 \mathrm{H}), 8.39(\mathrm{dd}, J=7.8,1.7 \mathrm{~Hz}$, $1 \mathrm{H}), 7.45-7.43(\mathrm{~m}, 1 \mathrm{H}), 7.15-7.12(\mathrm{~m}, 1 \mathrm{H}), 7.07(\mathrm{~d}, J=8.3 \mathrm{~Hz}, 1 \mathrm{H}), 4.08(\mathrm{~s}, 3 \mathrm{H}), 3.67(\mathrm{~s}$, $3 \mathrm{H}), 3.45(\mathrm{~s}, 3 \mathrm{H}) \mathrm{ppm} .{ }^{13} \mathrm{C}-\mathrm{NMR}\left(126 \mathrm{MHz}, \mathrm{CDCl}_{3}\right) \delta=157.04,155.06,152.05,148.59,148.52$, 132.02, 130.09, 121.81, 116.45, 111.53, 106.95, 56.17, 30.23, 28.39 ppm. MS (ESI+): m/z calculated for $\mathrm{C}_{14} \mathrm{H}_{15} \mathrm{~N}_{4} \mathrm{O}_{3}\left([\mathrm{M}+\mathrm{H}]^{+}\right)$287.11, found 287.06. HRMS (MALDI): $\mathrm{m} / z$ calculated for $\mathrm{C}_{14} \mathrm{H}_{15} \mathrm{~N}_{4} \mathrm{O}_{3}\left([\mathrm{M}+\mathrm{H}]^{+}\right)$287.11387, found 287.11429.

8-(3-Methoxyphenyl)-1,3-dimethyl-3,7-dihydro-1H-purine-2,6-dione (23). 23 was prepared according to the general procedure for Suzuki coupling reaction using 8-bromotheophylline (13, $200 \mathrm{mg}, 0.772 \mathrm{mmol}, 1.00 \mathrm{eq}), \mathrm{Na}_{2} \mathrm{CO}_{3}$ (246 mg, $2.32 \mathrm{mmol}, 3.00 \mathrm{eq}$ ), 3methoxyphenylboronic acid (35e, $141 \mathrm{mg}, 0.926 \mathrm{mmol}, 1.20 \mathrm{eq})$ and $\mathrm{Pd}\left(\mathrm{PPh}_{3}\right)_{4}(45 \mathrm{mg}, 0.039$ mmol, 0.05 eq) suspended in a $10 \mathrm{~mL}$ degassed dioxane $/ \mathrm{H}_{2} \mathrm{O}$ mixture under argon atmosphere. The product was obtained as a colorless solid (22 $\mathrm{mg}, 10 \%) . \mathrm{R}_{\mathrm{f}}=0.6(2: 1$ ethyl acetate/n-hexane). ${ }^{1} \mathrm{H}-\mathrm{NMR}(500 \mathrm{MHz}$, DMSO-d 6$) \delta=13.83(\mathrm{~s}, 1 \mathrm{H}), 7.74-7.71(\mathrm{~m}, 2 \mathrm{H}), 7.41$ 
(t, $J=8.2 \mathrm{~Hz}, 1 \mathrm{H}), 7.05-7.03(\mathrm{~m}, 1 \mathrm{H}), 3.83(\mathrm{~s}, 3 \mathrm{H}), 3.50(\mathrm{~s}, 3 \mathrm{H}), 3.26(\mathrm{~s}, 3 \mathrm{H}) \mathrm{ppm} .{ }^{13} \mathrm{C}-\mathrm{NMR}$ $\left(126 \mathrm{MHz}\right.$, DMSO-d $\left.\mathrm{d}_{6}\right) \delta=159.61,154.25,151.22,149.54,148.43,130.14,129.93,118.83$, 116.46, 111.01, 107.70, 55.34, 29.81, 27.84 ppm. MS (ESI+): $\mathrm{m} / z$ calculated for $\mathrm{C}_{14} \mathrm{H}_{15} \mathrm{~N}_{4} \mathrm{O}_{3}$ $\left([\mathrm{M}+\mathrm{H}]^{+}\right)$287.11, found 287.12. HRMS (MALDI): $\mathrm{m} / \mathrm{z}$ calculated for $\mathrm{C}_{14} \mathrm{H}_{15} \mathrm{~N}_{4} \mathrm{O}_{3}\left([\mathrm{M}+\mathrm{H}]^{+}\right)$ 287.11387, found 287.11433.

8-(4-Methoxyphenyl)-1,3-dimethyl-3,7-dihydro-1H-purine-2,6-dione (24). 24 was prepared according to the general procedure for Suzuki coupling reaction using 8-bromotheophylline (13, $200 \mathrm{mg}, 0.772 \mathrm{mmol}, 1.00 \mathrm{eq}), \mathrm{Na}_{2} \mathrm{CO}_{3}$ (246 mg, $2.32 \mathrm{mmol}, 3.00 \mathrm{eq}$ ), 4methoxyphenylboronic acid (35f, $141 \mathrm{mg}, 0.926 \mathrm{mmol}, 1.20 \mathrm{eq})$ and $\mathrm{Pd}\left(\mathrm{PPh}_{3}\right)_{4}(45 \mathrm{mg}, 0.039$ mmol, 0.05 eq) suspended in a $10 \mathrm{~mL}$ degassed dioxane $/ \mathrm{H}_{2} \mathrm{O}$ mixture under argon atmosphere. The product was obtained as a colorless solid (106 mg, 48\%). $R_{f}=0.4$ (2:1 ethyl acetate/n-hexane). ${ }^{1} \mathrm{H}-\mathrm{NMR}\left(500 \mathrm{MHz}, \mathrm{DMSO}_{\mathrm{d}}\right) \delta=13.63(\mathrm{~s}, 1 \mathrm{H}), 8.09(\mathrm{~d}, \mathrm{~J}=8.8 \mathrm{~Hz}, 2 \mathrm{H})$, $7.07(\mathrm{~d}, \mathrm{~J}=8.8 \mathrm{~Hz}, 2 \mathrm{H}), 3.82(\mathrm{~s}, 3 \mathrm{H}), 3.50(\mathrm{~s}, 3 \mathrm{H}), 3.26(\mathrm{~s}, 3 \mathrm{H}) \mathrm{ppm} .{ }^{13} \mathrm{C}-\mathrm{NMR}(126 \mathrm{MHz}$, DMSO-d $\left.d_{6}\right) \delta=160.90,154.13,151.26,150.00,148.64,128.12,121.24,114.43,107.23,55.41$, 29.79, $27.81 \mathrm{ppm}$. MS (ESI+): $\mathrm{m} / z$ calculated for $\mathrm{C}_{14} \mathrm{H}_{15} \mathrm{~N}_{4} \mathrm{O}_{3}\left([\mathrm{M}+\mathrm{H}]^{+}\right)$287.11, found 287.10. HRMS (MALDI): $m / z$ calculated for $\mathrm{C}_{14} \mathrm{H}_{15} \mathrm{~N}_{4} \mathrm{O}_{3}\left([\mathrm{M}+\mathrm{H}]^{+}\right)$287.11387, found 287.11407.

8-([1,1'-Biphenyl]-2-yl)-1,3-dimethyl-3,7-dihydro-1H-purine-2,6-dione (25). 25 was prepared according to the general procedure for Suzuki coupling reaction using 8-bromotheophylline (13, $200 \mathrm{mg}, 0.772 \mathrm{mmol}, 1.00 \mathrm{eq}$ ), $\mathrm{Na}_{2} \mathrm{CO}_{3}$ (246 mg, $2.32 \mathrm{mmol}, 3.00 \mathrm{eq}$ ), [1,1'-biphenyl]-2ylboronic acid (35g, $184 \mathrm{mg}, 0.926 \mathrm{mmol}, 1.20 \mathrm{eq})$ and $\mathrm{Pd}\left(\mathrm{PPh}_{3}\right)_{4}(45 \mathrm{mg}, 0.039 \mathrm{mmol}, 0.05$ eq) suspended in a $10 \mathrm{~mL}$ degassed dioxane $/ \mathrm{H}_{2} \mathrm{O}$ mixture under argon atmosphere. The product was obtained as a colorless solid (100 mg, 39\%). $R_{f}=0.5$ (1:1 ethyl acetate/ $n$-hexane). ${ }^{1} \mathrm{H}-\mathrm{NMR}(500 \mathrm{MHz} \text {, DMSO-d })_{6} \delta=13.29(\mathrm{~s}, 1 \mathrm{H}), 7.67$ (dd, $\left.J=7.6,1.0 \mathrm{~Hz}, 1 \mathrm{H}\right), 7.61$ (td, $\mathrm{J}=$ 7.6, $1.4 \mathrm{~Hz}, 1 \mathrm{H}), 7.54-7.47(\mathrm{~m}, 2 \mathrm{H}), 7.36-7.25(\mathrm{~m}, 3 \mathrm{H}), 7.18-7.14(\mathrm{~m}, 2 \mathrm{H}), 3.33(\mathrm{~s}, 3 \mathrm{H})$, $3.21(\mathrm{~s}, 3 \mathrm{H}) \mathrm{ppm} .{ }^{13} \mathrm{C}-\mathrm{NMR}(126 \mathrm{MHz}$, DMSO-d 6 ) $\delta=154.17,151.11,150.64,148.04,141.30$, 140.10, 130.69, 130.59, 130.31, 128.87, 128.36, 128.07, 127.45, 127.09, 107.08, 29.66, 27.77 ppm. MS (ESI+): $\mathrm{m} / z$ calculated for $\mathrm{C}_{19} \mathrm{H}_{17} \mathrm{~N}_{4} \mathrm{O}_{2}\left([\mathrm{M}+\mathrm{H}]^{+}\right)$333.13, found 333.06. HRMS (MALDI): $m / z$ calculated for $\mathrm{C}_{19} \mathrm{H}_{17} \mathrm{~N}_{4} \mathrm{O}_{2}\left([\mathrm{M}+\mathrm{H}]^{+}\right) 333.13460$, found 333.13478 .

8-([1,1'-Biphenyl]-3-yl)-1,3-dimethyl-3,7-dihydro-1H-purine-2,6-dione (26). 26 was prepared according to the general procedure for Suzuki coupling reaction using 8-bromotheophylline (13, $200 \mathrm{mg}, 0.772 \mathrm{mmol}, 1.00 \mathrm{eq}$ ), $\mathrm{Na}_{2} \mathrm{CO}_{3}$ (246 mg, $2.32 \mathrm{mmol}, 3.00 \mathrm{eq}$ ), [1,1'-biphenyl]-3ylboronic acid (35h, $184 \mathrm{mg}, 0.926 \mathrm{mmol}, 1.20 \mathrm{eq})$ and $\mathrm{Pd}\left(\mathrm{PPh}_{3}\right)_{4}(45 \mathrm{mg}, 0.039 \mathrm{mmol}, 0.05$ eq) suspended in a $10 \mathrm{~mL}$ degassed dioxane/ $\mathrm{H}_{2} \mathrm{O}$ mixture under argon atmosphere. The product was obtained as a colorless solid ( $117 \mathrm{mg}, 46 \%) . R_{f}=0.4$ (2:1 ethyl acetate $/ n$-hexane). ${ }^{1} \mathrm{H}-\mathrm{NMR}(500 \mathrm{MHz}$, DMSO-d 6 ) $\delta=13.99(\mathrm{~s}, 1 \mathrm{H}), 8.50(\mathrm{~s}, 1 \mathrm{H}), 8.13(\mathrm{~d}, J=7.3 \mathrm{~Hz}, 1 \mathrm{H}), 7.80$ (t, $J=7.1 \mathrm{~Hz}, 2 \mathrm{H}), 7.61(\mathrm{t}, J=7.7 \mathrm{~Hz}, 1 \mathrm{H}), 7.52(\mathrm{t}, J=7.4 \mathrm{~Hz}, 3 \mathrm{H}), 7.42(\mathrm{t}, J=7.1 \mathrm{~Hz}, 1 \mathrm{H}), 3.53$ 
(s, 3H), 3.28 (s, 3H) ppm. ${ }^{13} \mathrm{C}-\mathrm{NMR}\left(126 \mathrm{MHz}, \mathrm{DMSO}-\mathrm{d}_{6}\right) \delta=154.29,151.25,149.57,148.51$, 140.76, 139.28, 129.75, 129.31, 129.04, 128.32, 127.97, 126.79, 125.55, 124.35, 107.83, 29.86, 27.86 ppm. MS (ESI+): $\mathrm{m} / z$ calculated for $\mathrm{C}_{19} \mathrm{H}_{17} \mathrm{~N}_{4} \mathrm{O}_{2}\left([\mathrm{M}+\mathrm{H}]^{+}\right) 333.13$, found 333.11. HRMS (MALDI): $m / z$ calculated for $\mathrm{C}_{19} \mathrm{H}_{16} \mathrm{~N}_{4} \mathrm{O}_{2} \mathrm{Na}\left([\mathrm{M}+\mathrm{Na}]^{+}\right) 355.11655$, found 355.11682 .

8-([1,1'-Biphenyl]-4-yl)-1,3-dimethyl-3,7-dihydro-1H-purine-2,6-dione (27). 27 was prepared according to the general procedure for Suzuki coupling reaction using 8-bromotheophylline (13, $200 \mathrm{mg}, 0.772 \mathrm{mmol}, 1.00 \mathrm{eq}$ ), $\mathrm{Na}_{2} \mathrm{CO}_{3}$ (246 mg, $2.32 \mathrm{mmol}, 3.00 \mathrm{eq}$ ), [1,1'-biphenyl]-4ylboronic acid (35i, $184 \mathrm{mg}, 0.926 \mathrm{mmol}, 1.20 \mathrm{eq})$ and $\mathrm{Pd}\left(\mathrm{PPh}_{3}\right)_{4}(45 \mathrm{mg}, 0.039 \mathrm{mmol}, 0.05$ eq) suspended in a $10 \mathrm{~mL}$ degassed dioxane $/ \mathrm{H}_{2} \mathrm{O}$ mixture under argon atmosphere. The product was obtained as a colorless solid ( $88 \mathrm{mg}, 34 \%) . \mathrm{R}_{\mathrm{f}}=0.5$ (2:1 ethyl acetate/ $n$-hexane). ${ }^{1} \mathrm{H}-\mathrm{NMR}\left(500 \mathrm{MHz}, \mathrm{DMSO}_{-} \mathrm{d}_{6}\right) \delta=13.92(\mathrm{~s}, 1 \mathrm{H}), 8.24(\mathrm{~d}, \mathrm{~J}=8.5 \mathrm{~Hz}, 2 \mathrm{H}), 7.84(\mathrm{~d}, \mathrm{~J}=8.6 \mathrm{~Hz}$, 2H), $7.78-7.68(\mathrm{~m}, 2 \mathrm{H}), 7.50(\mathrm{t}, \mathrm{J}=7.6 \mathrm{~Hz}, 2 \mathrm{H}), 7.41(\mathrm{t}, \mathrm{J}=7.4 \mathrm{~Hz}, 1 \mathrm{H}), 3.53(\mathrm{~s}, 3 \mathrm{H}), 3.28$ (s, 3H) ppm. ${ }^{13} \mathrm{C}-\mathrm{NMR}\left(126 \mathrm{MHz}, \mathrm{DMSO}-\mathrm{d}_{6}\right) \delta=154.25,151.24,149.42,148.61,141.63$, $139.07,129.08,128.05,127.68,127.16,126.99,126.74,107.80,29.83,27.87$ ppm. MS (ESI+): $m / z$ calculated for $\mathrm{C}_{19} \mathrm{H}_{17} \mathrm{~N}_{4} \mathrm{O}_{2}\left([\mathrm{M}+\mathrm{H}]^{+}\right)$333.13, found 333.05. HRMS (MALDI): $\mathrm{m} / \mathrm{z}$ calculated for $\mathrm{C}_{19} \mathrm{H}_{17} \mathrm{~N}_{4} \mathrm{O}_{2}\left([\mathrm{M}+\mathrm{H}]^{+}\right)$333.13460, found 333.13541.

8-(Furan-2-yl)-1,3-dimethyl-3,7-dihydro-1H-purine-2,6-dione (28). 28 was prepared according to the general procedure for Suzuki coupling reaction using 8-bromotheophylline $(13,200 \mathrm{mg}$, $0.772 \mathrm{mmol}, 1.00 \mathrm{eq}$ ), $\mathrm{Na}_{2} \mathrm{CO}_{3}$ (246 mg, $2.32 \mathrm{mmol}, 3.00 \mathrm{eq}$ ), furan-2-ylboronic acid (35j, 104 $\mathrm{mg}, 0.926 \mathrm{mmol}, 1.20 \mathrm{eq})$ and $\mathrm{Pd}\left(\mathrm{PPh}_{3}\right)_{4}(45 \mathrm{mg}, 0.039 \mathrm{mmol}, 0.05 \mathrm{eq})$ suspended in a $10 \mathrm{~mL}$ degassed dioxane $/ \mathrm{H}_{2} \mathrm{O}$ mixture under argon atmosphere. The product was obtained as a colorless solid (72 mg, 38\%). $\mathrm{R}_{\mathrm{f}}=0.5$ (2:1 ethyl acetate/ $n$-hexane). ${ }^{1} \mathrm{H}-\mathrm{NMR}$ (500 MHz, DMSO$\left.\mathrm{d}_{6}\right) \delta=13.91(\mathrm{~s}, 1 \mathrm{H}), 7.90(\mathrm{dd}, J=1.6,0.6 \mathrm{~Hz}, 1 \mathrm{H}), 7.22(\mathrm{~d}, J=3.1 \mathrm{~Hz}, 1 \mathrm{H}), 6.70(\mathrm{dd}, J=3.5$, $1.8 \mathrm{~Hz}, 1 \mathrm{H}), 3.47(\mathrm{~s}, 3 \mathrm{H}), 3.25(\mathrm{~s}, 3 \mathrm{H}) \mathrm{ppm} .{ }^{13} \mathrm{C}-\mathrm{NMR}\left(126 \mathrm{MHz}, \mathrm{DMSO}-\mathrm{d}_{6}\right) \delta=154.14,151.19$, $148.51,145.18,144.04,142.04,112.38,111.48,106.99,29.83,27.85$ ppm. MS (ESI+): m/z calculated for $\mathrm{C}_{11} \mathrm{H}_{11} \mathrm{~N}_{4} \mathrm{O}_{3}\left([\mathrm{M}+\mathrm{H}]^{+}\right)$247.08, found 247.03. HRMS (MALDI): $m / z$ calculated for $\mathrm{C}_{11} \mathrm{H}_{11} \mathrm{~N}_{4} \mathrm{O}_{3}\left([\mathrm{M}+\mathrm{H}]^{+}\right)$247.08257, found 247.08285.

8-(Furan-3-yl)-1,3-dimethyl-3,7-dihydro-1H-purine-2,6-dione (29). 29 was prepared according to the general procedure for Suzuki coupling reaction using 8-bromotheophylline $(\mathbf{1 3}, 200 \mathrm{mg}$, $0.772 \mathrm{mmol}, 1.00 \mathrm{eq}$ ), $\mathrm{Na}_{2} \mathrm{CO}_{3}$ (246 mg, $2.32 \mathrm{mmol}, 3.00 \mathrm{eq}$ ), furan-3-ylboronic acid (35k, 104 $\mathrm{mg}, 0.926 \mathrm{mmol}, 1.20 \mathrm{eq})$ and $\mathrm{Pd}\left(\mathrm{PPh}_{3}\right)_{4}(45 \mathrm{mg}, 0.039 \mathrm{mmol}, 0.05 \mathrm{eq})$ suspended in a $10 \mathrm{~mL}$ degassed dioxane $/ \mathrm{H}_{2} \mathrm{O}$ mixture under argon atmosphere. The product was obtained as a colorless solid (26 mg, 14\%). $\mathrm{R}_{\mathrm{f}}=0.6$ (2:1 ethyl acetate/ $n$-hexane). ${ }^{1} \mathrm{H}-\mathrm{NMR}$ (500 MHz, DMSO$\left.\mathrm{d}_{6}\right) \delta=13.67(\mathrm{~s}, 1 \mathrm{H}), 8.36(\mathrm{~d}, J=0.6 \mathrm{~Hz}, 1 \mathrm{H}), 7.83(\mathrm{t}, J=1.7 \mathrm{~Hz}, 1 \mathrm{H}), 7.09-7.05(\mathrm{~m}, 1 \mathrm{H})$, $3.46(\mathrm{~s}, 3 \mathrm{H}), 3.25(\mathrm{~s}, 3 \mathrm{H}) \mathrm{ppm} .{ }^{13} \mathrm{C}-\mathrm{NMR}\left(126 \mathrm{MHz}, \mathrm{DMSO}-\mathrm{d}_{6}\right) \delta=154.10,151.21,148.53$, $144.81,144.52,143.02,116.77,108.52,106.73,29.85,27.80$ ppm. MS (ESI+): $m / z$ calculated 
for $\mathrm{C}_{11} \mathrm{H}_{11} \mathrm{~N}_{4} \mathrm{O}_{3}\left([\mathrm{M}+\mathrm{H}]^{+}\right)$247.08, found 247.03. HRMS (MALDI): $m / z$ calculated for $\mathrm{C}_{11} \mathrm{H}_{11} \mathrm{~N}_{4} \mathrm{O}_{3}$ $\left([\mathrm{M}+\mathrm{H}]^{+}\right)$247.08257, found 247.08276.

8-(3,4-Dimethoxystyryl)-1,3-dimethyl-3,7-dihydro-1H-purine-2,6-dione (31). N-(6-Amino-1,3dimethyl-2,4-dioxo-1,2,3,4-tetrahydropyrimidin-5-yl)-3-(3,4-dimethoxyphenyl)acrylamide (38d, $32 \mathrm{mg}, 0.090 \mathrm{mmol}, 1.00 \mathrm{eq}$ ) was suspended in $1.5 \mathrm{~mL}$ DMSO. NaOH (36 mg, $0.90 \mathrm{mmol}, 10$ eq) were dissolved in $1.5 \mathrm{~mL} \mathrm{H}_{2} \mathrm{O}$ and added to the previous solution. The resulting greenish solution was stirred at $100^{\circ} \mathrm{C}$ for 3 hours. After cooling to room temperature, $10 \mathrm{~mL} 5 \%$ aqueous $\mathrm{HCl}$ solution was added which caused precipitation of a solid. The resulting suspension was stirred for 30 minutes at room temperature. The precipitate was filtered off and washed with hot water. The product was obtained as a yellow solid ( $8 \mathrm{mg}, 25 \%)$. $R_{f}=0.5$ (9:1 methylene chloride/methanol). ${ }^{1} \mathrm{H}-\mathrm{NMR}\left(500 \mathrm{MHz}, \mathrm{DMSO}-\mathrm{d}_{6}\right) \delta=7.60(\mathrm{~d}, J=16.3 \mathrm{~Hz}$, $1 \mathrm{H}), 7.25$ (d, $J=1.4 \mathrm{~Hz}, 1 \mathrm{H}), 7.13(\mathrm{dd}, J=8.3,1.5 \mathrm{~Hz}, 1 \mathrm{H}), 6.99(\mathrm{~d}, J=8.4 \mathrm{~Hz}, 1 \mathrm{H}), 6.94(\mathrm{~d}$, $J=16.3 \mathrm{~Hz}, 1 \mathrm{H}), 3.82(\mathrm{~s}, 3 \mathrm{H}), 3.79(\mathrm{~s}, 3 \mathrm{H}), 3.47(\mathrm{~s}, 3 \mathrm{H}), 3.25(\mathrm{~s}, 3 \mathrm{H}) \mathrm{ppm} .{ }^{13} \mathrm{C}-\mathrm{NMR}(126 \mathrm{MHz}$, DMSO-d $d_{6} \delta=153.94,151.19,149.94,149.88,149.04,148.58,135.43,128.27,121.03$, 113.48, 111.79, 109.58, 106.84, 55.56, 55.53, 29.73, 27.74 ppm. MS (ESI+): m/z calculated for $\mathrm{C}_{17} \mathrm{H}_{19} \mathrm{~N}_{4} \mathrm{O}_{4}\left([\mathrm{M}+\mathrm{H}]^{+}\right)$343.13, found 343.00. HRMS (MALDI): $m / z$ calculated for $\mathrm{C}_{17} \mathrm{H}_{19} \mathrm{~N}_{4} \mathrm{O}_{4}$ $\left([\mathrm{M}+\mathrm{H}]^{+}\right)$343.14008, found 343.14009.

8-(3,4-Dimethoxyphenethyl)-1,3-dimethyl-3,7-dihydro-1H-purine-2,6-dione (32). N-(6-Amino1,3-dimethyl-2,4-dioxo-1,2,3,4-tetrahydropyrimidin-5-yl)-3-(3,4-

dimethoxyphenyl)propanamide (38e, $52 \mathrm{mg}, 0.14 \mathrm{mmol}, 1.0 \mathrm{eq}$ ) was suspended in $5 \mathrm{~mL} \mathrm{H}_{2} \mathrm{O}$. $\mathrm{NaOH}\left(57 \mathrm{mg}, 1.4 \mathrm{mmol}, 10 \mathrm{eq}\right.$ ) was added and the greenish solution was stirred at $100^{\circ} \mathrm{C}$ for 2 hours. After cooling to room temperature $20 \mathrm{~mL}$ aqueous $\mathrm{HCl}(5 \% \mathrm{v} / \mathrm{v})$ solution was added. Phases were separated and the aqueous layer was extracted five times with $20 \mathrm{~mL}$ ethyl acetate at a time. The combined organic layers were dried over $\mathrm{Na}_{2} \mathrm{SO}_{4}$ and the solvents were evaporated under reduced pressure. The product was obtained as a colorless solid (40 mg, $81 \%) . R_{f}=0.7$ (9:1 methylene chloride/methanol). ${ }^{1} \mathrm{H}-\mathrm{NMR}\left(500 \mathrm{MHz}, \mathrm{DMSO}-\mathrm{d}_{6}\right) \delta=13.19(\mathrm{~s}$, $1 \mathrm{H}), 6.86-6.81(\mathrm{~m}, 2 \mathrm{H}), 6.70(\mathrm{dd}, J=8.1,1.6 \mathrm{~Hz}, 1 \mathrm{H}), 3.71(\mathrm{~s}, 3 \mathrm{H}), 3.70(\mathrm{~s}, 3 \mathrm{H}), 3.43(\mathrm{~s}, 3 \mathrm{H})$, $3.23(\mathrm{~s}, 3 \mathrm{H}), 2.99-2.93(\mathrm{~m}, 4 \mathrm{H}) \mathrm{ppm} .{ }^{13} \mathrm{C}-\mathrm{NMR}\left(126 \mathrm{MHz}, \mathrm{DMSO}-\mathrm{d}_{6}\right) \delta=153.98,153.52$, 151.18, 148.59, 148.02, 147.20, 132.94, 120.00, 112.20, 111.85, 105.98, 55.49, 55.34, 32.87, 30.34, 29.72, 27.66 ppm. MS (ESI+): $m / z$ calculated for $\mathrm{C}_{17} \mathrm{H}_{21} \mathrm{~N}_{4} \mathrm{O}_{4}\left([\mathrm{M}+\mathrm{H}]^{+}\right) 345.15$, found 345.02. HRMS (MALDI): $m / z$ calculated for $\mathrm{C}_{17} \mathrm{H}_{21} \mathrm{~N}_{4} \mathrm{O}_{4}\left([\mathrm{M}+\mathrm{H}]^{+}\right) 345.15573$, found 345.15608 .

1,3-Diethyl-8-(furan-3-yl)-3,7-dihydro-1H-purine-2,6-dione (33). $\quad \mathrm{N}$-(1,3-Diethyl-5-nitro-2,6dioxo-1,2,3,6-tetrahydropyrimidin-4-yl)furan-3-carboxamide $(44,140 \mathrm{mg}, 0.433 \mathrm{mmol}, 1.00$ eq) was dissolved in aqueous $\mathrm{NH}_{3}$ solution $(12.5 \%, 3 \mathrm{~mL})$. The purple solution was heated to $80^{\circ} \mathrm{C}$ and $\mathrm{Na}_{2} \mathrm{~S}_{2} \mathrm{O}_{4}(249 \mathrm{mg}, 1.43 \mathrm{mmol}, 3.30 \mathrm{eq})$ was added. After 4 hour stirring at $80^{\circ} \mathrm{C}$, $\mathrm{NaOH}\left(173 \mathrm{mg}, 4.33 \mathrm{mmol}, 10.0 \mathrm{eq}\right.$ ) was added. The solution was stirred for 3 hours at $100^{\circ} \mathrm{C}$ 
and afterwards 17 hours at room temperature. Aqueous $\mathrm{HCl}$ solution ( $5 \% \mathrm{v} / \mathrm{v}, 20 \mathrm{~mL}$ ) was added and the mixture was stirred for 1 hour at room temperature. The precipitate was collected by filtration, washed with hot water, and dried in vacuo. 33 was obtained as a colorless solid (9 mg, 7\%). $\mathrm{R}_{\mathrm{f}}=0.4$ (2:1 $n$-hexane/ ethyl acetate). ${ }^{1} \mathrm{H}-\mathrm{NMR}$ (500 MHz, DMSO$\left.\mathrm{d}_{6}\right) \delta=13.67(\mathrm{~s}, 1 \mathrm{H}), 8.39-8.33(\mathrm{~m}, 1 \mathrm{H}), 7.83(\mathrm{~d}, J=3.4 \mathrm{~Hz}, 1 \mathrm{H}), 7.09(\mathrm{dd}, J=1.8,0.6 \mathrm{~Hz}$, $1 \mathrm{H}$ ), 4.06 (q, $J=7.1 \mathrm{~Hz}, 2 \mathrm{H}$ ), 3.94 (q, $J=7.0 \mathrm{~Hz}, 2 \mathrm{H}$ ), 1.25 (t, $J=7.0 \mathrm{~Hz}, 3 \mathrm{H}$ ), 1.14 (t, $J=7.0$ $\mathrm{Hz}, 3 \mathrm{H}) \mathrm{ppm} .{ }^{13} \mathrm{C}-\mathrm{NMR}(126 \mathrm{MHz}$, DMSO-d 6 ) $\delta=153.70,150.19,147.99,144.76,144.70$, 143.05, 116.74, 108.54, 106.91, 38.05, 35.70, $13.21 \mathrm{ppm}$. MS (ESI+): $\mathrm{m} / \mathrm{z}$ calculated for $\mathrm{C}_{13} \mathrm{H}_{15} \mathrm{~N}_{4} \mathrm{O}_{3}\left([\mathrm{M}+\mathrm{H}]^{+}\right)$275.11, found 275.14. HRMS (MALDI): $\mathrm{m} / \mathrm{z}$ calculated for $\mathrm{C}_{13} \mathrm{H}_{15} \mathrm{~N}_{4} \mathrm{O}_{3}$ $\left([\mathrm{M}+\mathrm{H}]^{+}\right)$275.11387, found 275.11417 .

8-(Furan-3-yl)-1,3-dipropyl-3,7-dihydro-1H-purine-2,6-dione (34). 5,6-Diamino-1,3dipropylpyrimidine-2,4(1H,3H)-dione (36b, $25 \mathrm{mg}, 0.095 \mathrm{mmol}, 1.0 \mathrm{eq})$ was dissolved in 0.5 $\mathrm{mL}$ chlorofrom and treated with triethylamine (13 $\mu \mathrm{L}, 0.095 \mathrm{mmol}, 1.0 \mathrm{eq})$. Subsequently, 3furoic acid (35f, $12 \mathrm{mg}, 0.10 \mathrm{mmol}, 1.1 \mathrm{eq})$ and $\mathrm{EDC} \cdot \mathrm{HCl}(22 \mathrm{mg}, 0.11 \mathrm{mmol}, 1.2 \mathrm{eq})$ were added and the resulting solution was stirred for 72 hours at room temperature. Aqueous saturated $\mathrm{K}_{2} \mathrm{CO}_{3}$ solution ( $30 \mathrm{~mL}$ ) was added, phases were separated, and the aqueous layer was extracted with methylene chloride $(5 \times 30 \mathrm{~mL})$. The combined organic layers were dried over $\mathrm{Na}_{2} \mathrm{SO}_{4}$, and the solvent was removed in vacuo to obtain $\mathrm{N}$-(6-amino-2,4-dioxo-1,3dipropyl-1,2,3,4-tetrahydropyrimidin-5-yl)furan-3-carboxamide (38f) which was used without further purification. The crude product (38f) was treated with aqueous $\mathrm{NaOH}$ solution (2 $\mathrm{M}, 2$ $\mathrm{mL}$ ) and the resulting solution was stirred for 2 hours at $100^{\circ} \mathrm{C}$. After cooling to room temperature, aqueous $\mathrm{HCl}$ solution $(5 \% \mathrm{v} / \mathrm{v}, 10 \mathrm{~mL})$ was added and the mixture was stirred for 24 hours at room temperature. The precipitate was filtered off and washed with hot water to obtain 34 as colorless solid ( $8 \mathrm{mg}, 24 \%$ over two steps). $R_{\mathrm{f}}=0.3$ (2:1 $n$-hexane/ethyl acetate). ${ }^{1} \mathrm{H}-\mathrm{NMR}(500 \mathrm{MHz}$, DMSO-d6) $\delta=13.65(\mathrm{~s}, 1 \mathrm{H}), 8.36(\mathrm{dd}, J=1.4,0.7 \mathrm{~Hz}, 1 \mathrm{H}), 7.83(\mathrm{t}, J=1.7$ $\mathrm{Hz}, 1 \mathrm{H}), 7.08(\mathrm{dd}, J=1.8,0.7 \mathrm{~Hz}, 1 \mathrm{H}), 4.01-3.96(\mathrm{~m}, 2 \mathrm{H}), 3.88-3.84(\mathrm{~m}, 2 \mathrm{H}), 1.77-1.68$ (m, 2H), $1.62-1.52(\mathrm{~m}, 2 \mathrm{H}), 0.88$ (q, J = 7.6 Hz, 6H) ppm. ${ }^{13} \mathrm{C}-\mathrm{NMR}(126 \mathrm{MHz}$, DMSO-d6) $\delta$ $=153.90,150.63,148.29,144.73,144.63,143.02,116.73,108.54,106.75,44.36,42.09$, 20.83, 20.79, 11.15, 10.97 ppm. MS (ESI+): $\mathrm{m} / z$ calculated for $\mathrm{C}_{15} \mathrm{H}_{19} \mathrm{~N}_{4} \mathrm{O}_{3}\left([\mathrm{M}+\mathrm{H}]^{+}\right) 303.14$, found 303.21. HRMS (MALDI): $\mathrm{m} / z$ calculated for $\mathrm{C}_{15} \mathrm{H}_{19} \mathrm{~N}_{4} \mathrm{O}_{3}\left([\mathrm{M}+\mathrm{H}]^{+}\right)$303.14517, found 303.14549 .

N-(6-Amino-1,3-dimethyl-2,4-dioxo-1,2,3,4-tetrahydropyrimidin-5-yl)-2-chlorobenzamide

(38a). 38a was prepared according to the general procedure for cyclization. 5,6-Diamino-1,3dimethylpyrimidine-2,4(1H,3H)-dione (36a, $100 \mathrm{mg}, 0.588 \mathrm{mmol}, 1.00 \mathrm{eq})$, 2-chlorobenzoic acid (37a, $101 \mathrm{mg}, 0.646 \mathrm{mmol}, 1.10 \mathrm{eq})$ and EDC. HCl (135 mg, $0.705 \mathrm{mmol}, 1.20 \mathrm{eq}$ ) were suspended in $10 \mathrm{~mL}$ of dry chloroform under argon atmosphere. The solution was stirred at 
room temperature for 72 hours. During reaction the product precipitated as a colorless solid. the solid was filtered off and washed with hot water. The product was obtained as a colorless solid (123 mg, 68\%). $\mathrm{R}_{\mathrm{f}}=0.4$ (9:1 methylene chloride/methanol). ${ }^{1} \mathrm{H}-\mathrm{NMR}$ (300 MHz, DMSO$\left.\mathrm{d}_{6}\right) \delta=8.95(\mathrm{~s}, 1 \mathrm{H}), 7.80(\mathrm{dd}, \mathrm{J}=7.2,1.7 \mathrm{~Hz}, 1 \mathrm{H}), 7.58-7.32(\mathrm{~m}, 3 \mathrm{H}), 6.54(\mathrm{~s}, 2 \mathrm{H}), 3.36(\mathrm{~s}$, $3 \mathrm{H}), 3.15(\mathrm{~s}, 3 \mathrm{H}) \mathrm{ppm} .{ }^{13} \mathrm{C}-\mathrm{NMR}\left(75 \mathrm{MHz}, \mathrm{DMSO}-\mathrm{d}_{6}\right) \delta=166.67,159.00,151.91,150.55$, 136.41, 130.89, 130.35, 129.90, 129.58, 126.70, 87.16, 30.06, 27.55 ppm. MS (ESI+): m/z calculated for $\mathrm{C}_{13} \mathrm{H}_{13} \mathrm{CIN}_{4} \mathrm{O}_{3} \mathrm{Na}\left([\mathrm{M}+\mathrm{Na}]^{+}\right) 331.06$, found 330.97 .

\section{N-(6-Amino-1,3-dimethyl-2,4-dioxo-1,2,3,4-tetrahydropyrimidin-5-yl)-3-chlorobenzamide}

(38b). 38b was prepared according to the general procedure for cyclization. 5,6-Diamino-1,3dimethylpyrimidine-2,4(1H,3H)-dione (36a, $100 \mathrm{mg}, 0.588 \mathrm{mmol}, 1.00 \mathrm{eq})$, 3-chlorobenzoic acid (37b, $101 \mathrm{mg}, 0.646 \mathrm{mmol}, 1.10 \mathrm{eq})$ and $\mathrm{EDC} \cdot \mathrm{HCl}(135 \mathrm{mg}, 0.705 \mathrm{mmol}, 1.20 \mathrm{eq}$ ) were suspended in $10 \mathrm{~mL}$ of dry chloroform under argon atmosphere. The solution was stirred at room temperature for 72 hours. During reaction the product precipitated as a colorless solid. the solid was filtered off and washed with hot water. The product was obtained as a colorless solid (146 mg, 80\%). $\mathrm{R}_{\mathrm{f}}=0.4$ (9:1 methylene chloride/methanol). ${ }^{1} \mathrm{H}-\mathrm{NMR}$ (300 MHz, DMSO$\left.\mathrm{d}_{6}\right) \delta=9.04(\mathrm{~s}, 1 \mathrm{H}), 8.04(\mathrm{t}, \mathrm{J}=1.7 \mathrm{~Hz}, 1 \mathrm{H}), 7.91(\mathrm{dt}, \mathrm{J}=7.7,1.3 \mathrm{~Hz}, 1 \mathrm{H}), 7.61$ (ddd, J = 8.0, 2.1, $1.1 \mathrm{~Hz}, 1 \mathrm{H}), 7.51(\mathrm{t}, \mathrm{J}=7.8 \mathrm{~Hz}, 1 \mathrm{H}), 3.33(\mathrm{~s}, 3 \mathrm{H}), 3.13(\mathrm{~s}, 3 \mathrm{H}) \mathrm{ppm} .{ }^{13} \mathrm{C}-\mathrm{NMR}(75 \mathrm{MHz}$, DMSO-d $d_{6} \delta=165.32,159.22,152.31,150.59,136.65,132.81,130.88,129.94,127.85$, 126.66, 87.08, 30.00, 27.52 ppm. MS (ESI+): $\mathrm{m} / z$ calculated for $\mathrm{C}_{13} \mathrm{H}_{13} \mathrm{CIN}_{4} \mathrm{O}_{3} \mathrm{Na}\left([\mathrm{M}+\mathrm{Na}]^{+}\right)$ 331.06 , found 330.97 .

\section{N-(6-Amino-1,3-dimethyl-2,4-dioxo-1,2,3,4-tetrahydropyrimidin-5-yl)-4-chlorobenzamide}

(38c). 38c was prepared according to the general procedure for cyclization. 5,6-Diamino-1,3dimethylpyrimidine-2,4(1H,3H)-dione (36a, $100 \mathrm{mg}, 0.588 \mathrm{mmol}, 1.00 \mathrm{eq})$, 4-chlorobenzoic acid (37c, $101 \mathrm{mg}, 0.646 \mathrm{mmol}, 1.10 \mathrm{eq})$ and EDC. $\mathrm{HCl}(135 \mathrm{mg}, 0.705 \mathrm{mmol}, 1.20 \mathrm{eq}$ ) were suspended in $10 \mathrm{~mL}$ of dry chloroform under argon atmosphere. The solution was stirred at room temperature for 24 hours. During reaction the product precipitated as a colorless solid. The solid was filtered off and washed with hot water. The product was obtained as a colorless solid (151 mg, 83\%). $\mathrm{R}_{\mathrm{f}}=0.4$ (9:1 methylene chloride/methanol). ${ }^{1} \mathrm{H}-\mathrm{NMR}$ (300 MHz, DMSO$\left.\mathrm{d}_{6}\right) \delta=9.00(\mathrm{~s}, 1 \mathrm{H}), 8.04-7.96(\mathrm{~m}, 2 \mathrm{H}), 7.60-7.52(\mathrm{~m}, 2 \mathrm{H}), 6.75(\mathrm{~s}, 2 \mathrm{H}), 3.34(\mathrm{~s}, 3 \mathrm{H}), 3.13$ $(\mathrm{s}, 3 \mathrm{H}) \mathrm{ppm} .{ }^{13} \mathrm{C}-\mathrm{NMR}\left(75 \mathrm{MHz}, \mathrm{DMSO}-\mathrm{d}_{6}\right) \delta=165.64,159.24,152.31,150.61,135.90$, 133.42, 129.93, 128.00, 87.21, 30.02, 27.53 ppm. MS (ESI+): $\mathrm{m} / \mathrm{z}$ calculated for $\mathrm{C}_{13} \mathrm{H}_{13} \mathrm{CIN}_{4} \mathrm{O}_{3} \mathrm{Na}\left([\mathrm{M}+\mathrm{Na}]^{+}\right)$331.06, found 331.17.

N-(6-Amino-1,3-dimethyl-2,4-dioxo-1,2,3,4-tetrahydropyrimidin-5-yl)-3-(3,4-

dimethoxyphenyl)acrylamide (38d). 5,6-Diamino-1,3-dimethylpyrimidine-2,4(1H,3H)-dione (36a, 50 mg, 0.29 mmol, 1.0 eq), 3-(3,4-dimethoxyphenyl)acrylic acid (37d, 67 mg, 0.32 mmol, $1.1 \mathrm{eq})$ and $\mathrm{EDC} \cdot \mathrm{HCl}(68 \mathrm{mg}, 0.35 \mathrm{mmol}, 1.2 \mathrm{eq})$ were suspended in $5 \mathrm{~mL}$ of dry chloroform 
under argon atmosphere. The solution was stirred at $50^{\circ} \mathrm{C}$ for 2 hours. During reaction the product precipitated as a colorless solid. After cooling to room temperature the solid was filtered off and washed with hot water. The product was obtained as a colorless solid (57 mg, $53 \%) . R_{f}=0.6\left(9: 1\right.$ methylene chloride/methanol). ${ }^{1} \mathrm{H}-\mathrm{NMR}\left(300 \mathrm{MHz}, \mathrm{DMSO}-\mathrm{d}_{6}\right) \delta=8.51(\mathrm{~s}$, $1 \mathrm{H}), 7.40(\mathrm{~d}, J=15.8 \mathrm{~Hz}, 1 \mathrm{H}), 7.20-7.13(\mathrm{~m}, 2 \mathrm{H}), 7.01(\mathrm{~d}, J=8.2 \mathrm{~Hz}, 1 \mathrm{H}), 6.72(\mathrm{~d}, J=15.8$ $\mathrm{Hz}, 1 \mathrm{H}), 6.64$ (bs, 2H), 3.81 (s, 3H), 3.80 (s, 3H), 3.32 (s, 3H), 3.13 (s, 3H) ppm. ${ }^{13} \mathrm{C}-\mathrm{NMR}(75$ MHz, DMSO-d 6 ) $\delta=165.57,159.25,151.86,150.54,150.09,148.90,138.76,127.83,121.14$, $120.41,111.85,110.10,87.61,55.54,55.42,29.99,27.54 \mathrm{ppm}$. MS (ESI+): $\mathrm{m} / z$ calculated for $\mathrm{C}_{19} \mathrm{H}_{25} \mathrm{~N}_{4} \mathrm{O}_{7}\left([\mathrm{M}+\mathrm{AcOH}]^{+}\right)$421.16, found 421.06 .

N-(6-Amino-1,3-dimethyl-2,4-dioxo-1,2,3,4-tetrahydropyrimidin-5-yl)-3-(3,4-

dimethoxyphenyl)propanamide (38e). 5,6-Diamino-1,3-dimethylpyrimidine-2,4(1H,3H)-dione (36a, $50 \mathrm{mg}, 0.29 \mathrm{mmol}, 1.0 \mathrm{eq}$ ), 3,4-dimethoxyphenylpropionic acid (37e, $68 \mathrm{mg}, 0.32 \mathrm{mmol}$, $1.1 \mathrm{eq})$ and $\mathrm{EDC} \cdot \mathrm{HCl}(68 \mathrm{mg}, 0.35 \mathrm{mmol}, 1.2 \mathrm{eq})$ were dissolved in $5 \mathrm{~mL}$ of dry chloroform under argon atmosphere. The solution was stirred at $50^{\circ} \mathrm{C}$ for 2 hours. After cooling to room temperature, $20 \mathrm{~mL}$ saturated aqueous $\mathrm{NaHCO}_{3}$ solution were added. Phases were separated and the aqueous layer was extracted five times with $20 \mathrm{~mL}$ chloroform at a time. The combined organic layers were dried over $\mathrm{Na}_{2} \mathrm{SO}_{4}$ and the solvent was removed under reduced pressure. The residue was supended in water, the crude product was filtered off and washed with hot water. The product was obtained as a colorless solid (56 mg, 52\%). $R_{f}=0.5(9: 1$ methylene chloride/methanol). ${ }^{1} \mathrm{H}-\mathrm{NMR}\left(300 \mathrm{MHz}, \mathrm{DMSO}_{-} \mathrm{d}_{6}\right) \delta=8.38(\mathrm{~s}, 1 \mathrm{H}), 6.88-6.82(\mathrm{~m}, 2 \mathrm{H}), 6.74$ (dd, $J=8.2,1.9 \mathrm{~Hz}, 1 \mathrm{H}), 6.44(\mathrm{bs}, 2 \mathrm{H}), 3.75(\mathrm{~s}, 3 \mathrm{H}), 3.72(\mathrm{~s}, 3 \mathrm{H}), 3.31(\mathrm{~s}, 3 \mathrm{H}), 3.11(\mathrm{~s}, 3 \mathrm{H})$, $2.84-2.76(\mathrm{~m}, 2 \mathrm{H}), 2.55-2.52(\mathrm{~m}, 2 \mathrm{H}) \mathrm{ppm} .{ }^{13} \mathrm{C}-\mathrm{NMR}\left(75 \mathrm{MHz}\right.$, DMSO-d $\left.\mathrm{d}_{6}\right) \delta=172.18$, 159.30, 151.98, 150.55, 148.64, 147.00, 134.08, 119.83, 112.17, 111.91, 87.51, 55.54, 55.34, $30.52,30.00,27.49$ ppm. MS (ESI+): $m / z$ calculated for $\mathrm{C}_{17} \mathrm{H}_{22} \mathrm{~N}_{4} \mathrm{O}_{5} \mathrm{Na}\left([\mathrm{M}+\mathrm{Na}]^{+}\right) 385.15$, found 385.06 .

2-Cyano-N-ethyl-N-(ethylcarbamoyl)acetamide (41). 1,3-Diethylurea (39, $1000 \mathrm{mg}, 8.609$ mmol, $1.000 \mathrm{eq})$ was treated with acetic anhydride (10.2 mL, $108 \mathrm{mmol}, 12.5 \mathrm{eq}) .2$ Cyanoacetic acid (40,806 mg, $9.47 \mathrm{mmol}, 1.10 \mathrm{eq})$ was added and the mixture was stirred for 2 hours at $80^{\circ} \mathrm{C}$. After cooling to room temperature, water $(30 \mathrm{~mL})$ was added, phases were separated, and the aqueous layer was extracted with methylene chloride $(4 \times 10 \mathrm{~mL})$. The combined organic layers were dried over $\mathrm{Na}_{2} \mathrm{SO}_{4}$ and the solvent was evaporated under reduced pressure. $\mathbf{4 1}$ was obtained as a pale yellow oil (834 mg, 53\%) and was used without further purification. $\mathrm{R}_{\mathrm{f}}=0.4$ (2:1 $\mathrm{n}$-hexane/ethyl acetate $+2 \%$ triethylamine). ${ }^{1} \mathrm{H}$-NMR (300 $\left.\mathrm{MHz}, \mathrm{CDCl}_{3}\right) \delta=8.57$ (bs, $\left.1 \mathrm{H}\right), 3.83-3.69(\mathrm{~m}, 4 \mathrm{H}), 3.34(\mathrm{qd}, J=7.3,5.4 \mathrm{~Hz}, 2 \mathrm{H}), 1.27$ (t, $J=$ $7.1 \mathrm{~Hz}, 3 \mathrm{H}), 1.19(\mathrm{t}, J=7.3 \mathrm{~Hz}, 3 \mathrm{H}) \mathrm{ppm} .{ }^{13} \mathrm{C}-\mathrm{NMR}\left(75 \mathrm{MHz}, \mathrm{CDCl}_{3}\right) \delta=165.29,153.24,40.36$, 
35.83, 28.27, 22.31, 14.86, 14.79 ppm. MS $(\mathrm{ESI}+): \mathrm{m} / z$ calculated for $\mathrm{C}_{8} \mathrm{H}_{13} \mathrm{~N}_{3} \mathrm{O}_{2} \mathrm{Na}\left([\mathrm{M}+\mathrm{Na}]^{+}\right)$ 206.09, found 205.97 .

\section{6-Amino-1,3-diethylpyrimidine-2,4(1H,3H)-dione}

(42).

2-Cyano- $N$-ethyl- $N$ -

(ethylcarbamoyl)acetamide $(\mathbf{4 1}, 834 \mathrm{mg}, 4.55 \mathrm{mmol}, 1.00 \mathrm{eq})$ was suspended in water (20 $\mathrm{mL}$ ), sodum hydroxide (182 $\mathrm{mg}, 4.55 \mathrm{mmol}, 1.00 \mathrm{eq}$ ) was added, and the suspension was stirred for 2 hours at $80^{\circ} \mathrm{C}$. After cooling to room temperature the colorless precipitate was collected by filtration and dried in vacuo to obtain 42 as a colorless solid (415 mg, 50\%). $R_{f}=$ 0 (9:1 methylene chloride/methanol). ${ }^{1} \mathrm{H}-\mathrm{NMR}\left(500 \mathrm{MHz}, \mathrm{DMSO}-\mathrm{d}_{6}\right) \delta=6.78(\mathrm{~s}, 1 \mathrm{H}), 4.65(\mathrm{~s}$, $1 \mathrm{H}$ ), 3.82 (q, J = 7.0 Hz, 2H), 3.74 (q, J=7.0 Hz, 2H), 1.10 (t, $J=7.0 \mathrm{~Hz}, 3 \mathrm{H}$ ), 1.02 (t, $J=7.0$ $\mathrm{Hz}, 3 \mathrm{H}) \mathrm{ppm} .{ }^{13} \mathrm{C}-\mathrm{NMR}(126 \mathrm{MHz}$, DMSO-d 6 ) $\delta=160.98,154.06,150.85,75.11,36.92,34.71$, 13.22, 13.16 ppm. MS (ESI+): $m / z$ calculated for $\mathrm{C}_{8} \mathrm{H}_{14} \mathrm{~N}_{3} \mathrm{O}_{2}\left([\mathrm{M}+\mathrm{H}]^{+}\right) 184.10$, found 184.22.

6-Amino-1,3-diethyl-5-nitropyrimidine-2,4(1H,3H)-dione (43). 6-Amino-1,3-diethylpyrimidine2,4(1H,3H)-dione $(42,415 \mathrm{mg}, 2.27 \mathrm{mmol}, 1.00 \mathrm{eq})$ was dissolved in a mixture of water (10 $\mathrm{mL}$ ) and acetic acid (10 mL). Sodium nitrite (188 mg, $2.72 \mathrm{mmol}, 1.20 \mathrm{eq})$ was added and the resultig purple solution was stirred for 2 hours at $60^{\circ} \mathrm{C}$. After cooling to room temperature, the solution was placed in an ice bath over night. The precipitate was removed by filtration. The filtrate was neutralized with $1 \mathrm{M}$ aqueous $\mathrm{NaOH}$ solution and extracted with ethyl acetate $(4 \mathrm{x}$ $20 \mathrm{~mL}$ ). The combined organic layers were dried over $\mathrm{Na}_{2} \mathrm{SO}_{4}$ and the solvent was evaporated under reduced pressure. 43 was obtained as a purple solid (267 mg, 52\%). $R_{f}=0.6(99: 1$ methylene chloride/methanol). ${ }^{1} \mathrm{H}-\mathrm{NMR}\left(500 \mathrm{MHz}, \mathrm{DMSO}-\mathrm{d}_{6}\right) \delta=13.17(\mathrm{~s}, 1 \mathrm{H}), 9.12(\mathrm{~s}, 1 \mathrm{H})$, $4.00-3.82(\mathrm{~m}, 4 \mathrm{H}), 1.24-0.97(\mathrm{~m}, 6 \mathrm{H}) \mathrm{ppm} .{ }^{13} \mathrm{C}-\mathrm{NMR}\left(126 \mathrm{MHz}, \mathrm{DMSO}-\mathrm{d}_{6}\right) \delta=159.71$, 148.60, 145.25, 139.06, 36.62, 36.03, 12.94, 12.00 ppm. MS (ESI+): $\mathrm{m} / \mathrm{z}$ calculated for $\mathrm{C}_{8} \mathrm{H}_{12} \mathrm{~N}_{4} \mathrm{O}_{4} \mathrm{Li}\left([\mathrm{M}+\mathrm{Li}]^{+}\right)$235.11, found 235.16.

N-(1,3-Diethyl-5-nitro-2,6-dioxo-1,2,3,6-tetrahydropyrimidin-4-yl)furan-3-carboxamide (44). 6Amino-1,3-diethyl-5-nitropyrimidine-2,4(1H,3H)-dione (43, $200 \mathrm{mg}, 0.876 \mathrm{mmol}, 1.00 \mathrm{eq}) 3-$ furoic acid (35f, $108 \mathrm{mg}, 0.964 \mathrm{mmol}, 1.10 \mathrm{eq})$ and $\mathrm{EDC} \cdot \mathrm{HCl}(202 \mathrm{mg}, 1.05 \mathrm{mmol}, 1.20 \mathrm{eq}$ ) were suspended in chloroform $(5 \mathrm{~mL})$. The resulting brown solution was stirred at room temperature for 23 hours. The crude product was purified by silica gel column chromatography (48:2 methylene chloride/methanol) to obtain 44 as a brown solid (140 mg, 49\%). $R_{f}=0.9$ (48:2 methylene chloride/methanol). Due to steric hindrance of the ethyl side chain atropisomerism is observed in ${ }^{1} \mathrm{H}$ - and ${ }^{13} \mathrm{C}-\mathrm{NMR}$ spectra with a 1:0.5:0.5 ratio. ${ }^{1} \mathrm{H}-\mathrm{NMR}$ (500 MHz, DMSO-d6) $\delta=8.38(\mathrm{dd}, J=1.5,0.7 \mathrm{~Hz}, 1 \mathrm{H}), 8.26(\mathrm{dd}, J=1.5,0.7 \mathrm{~Hz}, 0.5 \mathrm{H}), 7.94(\mathrm{dd}, J=1.5,0.8 \mathrm{~Hz}$, $0.5 \mathrm{H}), 7.54-7.53(\mathrm{~m}, 1 \mathrm{H}), 7.49-7.48(\mathrm{~m}, 0.5 \mathrm{H}), 7.47-7.46(\mathrm{~m}, 0.5 \mathrm{H}), 6.96(\mathrm{dd}, J=1.9,0.7$ $\mathrm{Hz}, 1 \mathrm{H}), 6.85(\mathrm{dd}, J=1.9,0.7 \mathrm{~Hz}, 0.5 \mathrm{H}), 6.78(\mathrm{dd}, J=1.9,0.8 \mathrm{~Hz}, 0.5 \mathrm{H}), 4.19(\mathrm{q}, J=7.0 \mathrm{~Hz}$, $1 \mathrm{H}), 4.12-3.95(\mathrm{~m}, 7 \mathrm{H}), 1.36(\mathrm{t}, J=7.0 \mathrm{~Hz}, 2 \mathrm{H}), 1.31-1.25(\mathrm{~m}, 10 \mathrm{H}) \mathrm{ppm} .{ }^{13} \mathrm{C}-\mathrm{NMR}(126$ $\mathrm{MHz}$, DMSO-d6) $\delta=172.20,158.00,157.22,156.00,152.03,151.62,150.67,150.41,149.02$, 
$148.98,147.29,144.79,144.70,143.97,141.26,138.64,134.73,123.62,115.80,115.63$, $110.05,109.89,40.18,38.49,38.04,37.90,13.28,13.25,13.23,12.71$ ppm. MS (MALDI+): $\mathrm{m} / z$ calculated for $\mathrm{C}_{13} \mathrm{H}_{15} \mathrm{~N}_{4} \mathrm{O}_{6} \mathrm{Na}\left([\mathrm{M}+\mathrm{H}+\mathrm{Na}]^{+}\right) 346.08$, found 345.98. 


\section{Supplementary References}

(1) Faudone, G.; Bischoff-Kont, I.; Rachor, L.; Willems, S.; Zhubi, R.; Kaiser, A.;

Chaikuad, A.; Knapp, S.; Fürst, R.; Heering, J.; Merk, D. Propranolol Activates the Orphan Nuclear Receptor TLX to Counteract Proliferation and Migration of Glioblastoma Cells. J. Med. Chem. 2021, 64 (12), 8727-8738.

(2) Benod, C.; Villagomez, R.; Filgueira, C. S.; Hwang, P. K.; Leonard, P. G.; PoncetMontange, G.; Rajagopalan, S.; Fletterick, R. J.; Gustafsson, J.-Å.; Webb, P. The Human Orphan Nuclear Receptor Tailless (TLX, NR2E1) Is Druggable. PLoS One 2014, 9 (6), e99440.

(3) Zhi, X.; Zhou, X. E.; He, Y.; Searose-Xu, K.; Zhang, C.-L.; Tsai, C.-C.; Melcher, K.; Xu, H. E. Structural Basis for Corepressor Assembly by the Orphan Nuclear Receptor TLX. Genes Dev. 2015, 29 (4), 440-450.

(4) Corso-Díaz, X.; de Leeuw, C. N.; Alonso, V.; Melchers, D.; Wong, B. K. Y.; Houtman, R.; Simpson, E. M. Co-Activator Candidate Interactions for Orphan Nuclear Receptor NR2E1. BMC Genomics 2016, 17 (1), 832.

(5) Bruns, R. F. Adenosine Antagonism by Purines, Pteridines and Benzopteridines in Human Fibroblasts. Biochem. Pharmacol. 1981, 30 (4), 325-333.

(6) Shamim, M. T.; Ukena, D.; Padgett, W. L.; Daly, J. W. Effects of 8-Phenyl and 8Cycloalkyl Substituents on the Activity of Mono-, Di-, and Trisubstituted Alkylxanthines with Substitution at the 1-, 3-, and 7-Positions. J. Med. Chem. 1989, 32 (6), 12311237.

(7) Van Galen, P. J. M.; Van Bergen, A. H.; Gallo-Rodriguez, C.; Melman, N.; Olah, M. E.; ljzerman, A. D. P.; Stiles, G. L.; Jacobson, K. A. A Binding Site Model and StructureActivity Relationships for the Rat A3 Adenosine Receptor. Mol. Pharmacol. 1994, 45 (6), 1101-1111.

(8) Müller, C. E.; Jacobson, K. A. Xanthines as Adenosine Receptor Antagonists. Handbook of Experimental Pharmacology. Springer, Berlin, Heidelberg 2011, pp 151199.

(9) Müller, C. E.; Jacobson, K. A. Recent Developments in Adenosine Receptor Ligands and Their Potential as Novel Drugs. Biochim. Biophys. Acta - Biomembr. 2011, 1808 (5), 1290-1308.

(10) Hunter, R. E.; Barrera, C. M.; Dohanich, G. P.; Dunlap, W. P. Effects of Uric Acid and Caffeine on A1 Adenosine Receptor Binding in Developing Rat Brain. Pharmacol. Biochem. Behav. 1990, 35 (4), 791-795.

(11) Daly, J. W.; Padgett, W.; Shamim, M. T.; Butts-Lamb, P.; Waters, J. 1,3-Dialkyl-8-(pSulfophenyl)Xanthines: Potent Water-Soluble Antagonists for A1 -and A2-Adenosine 
Receptors. J. Med. Chem. 1985, 28 (4), 487-492.

(12) Jacobson, K. A.; Kiriasis, L.; Barone, S.; Bradbury, B. J.; Campagne, J. M.; Secunda, S.; Daly, J. W.; Kammula, U.; Neumeyer, J. L.; Pfleiderer, W. Sulfur-Containing 1,3Dialkylxanthine Derivatives as Selective Antagonists at Al-Adenosine Receptors. J. Med. Chem. 1989, 32 (8), 1873-1879.

(13) Bruns, R. F.; Daly, J. W.; Snyder, S. H. Adenosine Receptor Binding: Structure-Activity Analysis Generates Extremely Potent Xanthine Antagonists. Proc. Natl. Acad. Sci. U. S. A. 1983, 80 (7 I), 2077-2080.

(14) Hamilton, H. W.; Ortwine, D. F.; Worth, D. F.; Badger, E. W.; Bristol, J. A.; Bruns, R. F.; Haleen, S. J.; Steffen, R. P. Synthesis of Xanthines as Adenosine Antagonists, a Practical Quantitative Structure-Activity Relationship Application. J. Med. Chem. 1985, 28 (8), 1071-1079.

(15) Jacobson, K. A.; Gallo-Rodriguez, C.; Melman, N.; Fischer, B.; Maillard, M.; van Bergen, A.; van Galen, P. J. M.; Karton, Y. Structure-Activity Relationships of 8Styrylxanthines as A2-Selective Adenosine Antagonists. J. Med. Chem. 1993, 36 (10), 1333-1342.

(16) Wilson, C. N. A1 Adenosine Receptor Antagonists. US20140031375A1, 2014.

(17) Hockemeyer, J.; Burbiel, J. C.; Müller, C. E. Multigram-Scale Syntheses, Stability, and Photoreactions of A2A Adenosine Receptor Antagonists with 8-Styrylxanthine Structure: Potential Drugs for Parkinson's Disease. J. Org. Chem. 2004, 69 (10), 3308-3318. 